Formerly Used Defense Sites Program - Innovative Technology Advocate

The Effect of Acid Neutralization on Analytical Results Produced from SW846 Method 8330 after the Alkaline Hydrolysis of Explosives in Soil

Steven L. Larson, Deborah R. Felt, Scott Waisner,

September 2012

Catherine C. Nestler, Charles G. Coyle, and Victor F. Medina 


\section{The Effect of Acid Neutralization on Analytical Results Produced from SW846 Method 8330 after the Alkaline Hydrolysis of Explosives in Soil}

Steven L. Larson, Deborah R. Felt, Scott Waisner, and Victor F. Medina

Environmental Laboratory

U.S. Army Engineer Research and Development Center

3909 Halls Ferry Road

Vicksburg, MS 39180-6199

Charles G. Coyle

USACE, Huntsville Engineering and Support Environmental \& Munitions CX

1616 Capitol Ave., Suite 9200

Omaha NE 68102-9200

Catherine C. Nestler

Applied Research Associates, Inc., Southern Division

119 Monument Place

Vicksburg, MS 39180

Final report

Approved for public release; distribution is unlimited.

Prepared for U.S. Army Corps of Engineers

Washington, DC 20314-1000 


\section{Abstract}

Alkaline hydrolysis has been used in several laboratory studies and field demonstrations for the treatment of energetic compounds (particularly, 2,4,6-trinitrotoluene (TNT), dinitrotoluene (DNT), and hexahydro-1,3,5trinitro-1,3,5-triazine (RDX)) in soil. The application of alkaline hydrolysis for treatment of soil involves mixing a caustic source material with soil. Two caustic materials have been explored, calcitic hydrated lime $\left[\mathrm{Ca}(\mathrm{OH})_{2}, \mathrm{HL}\right]$ and sodium hydroxide $(\mathrm{NaOH})$. Evaluation of explosives removal is routinely performed using SW-846 Method 8330. This method was developed before the advent of alkaline hydrolysis treatment, and recent studies have indicated that some errors can occur when this method is applied to alkaline hydrolysis samples. This report documents the results of a field study conducted to demonstrate the issue of false degradation in field-collected samples. The field study was followed by two laboratory studies: the first to confirm false degradation as a phenomenon and the second to develop an appropriate acid neutralization method. Results proved that false degradation can occur with alkaline hydrolysis (AH) samples, particularly if residual caustic material and moisture are present in the sample. Treatment systems using HL are more prone to extraction errors than systems using $\mathrm{NaOH}$, although neutralization improves the accuracy of both treatment approaches. ERDC-EL has developed a neutralization method that can be used for alkaline hydrolysis approaches using up to $10 \%$ caustic addition (most systems are less than $5 \%$ ) and a combination of $\mathrm{H}_{3} \mathrm{PO}_{4}$ and $\mathrm{NaH}_{2} \mathrm{PO}_{4}$. For remedial actions using alkaline hydrolysis, the scope of work for the action should include neutralization of all post- treatment samples, with appropriate control samples prepared in order to ensure that neutralization is achieved.

DISCLAIMER: The contents of this report are not to be used for advertising, publication, or promotional purposes. Citation of trade names does not constitute an official endorsement or approval of the use of such commercial products. All product names and trademarks cited are the property of their respective owners. The findings of this report are not to be construed as an official Department of the Army position unless so designated by other authorized documents. 


\section{Contents}
Abstract. ii

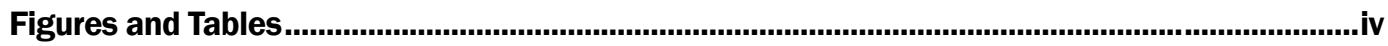

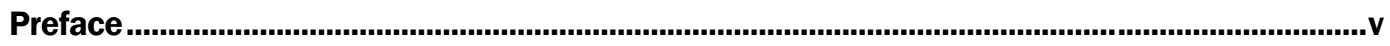

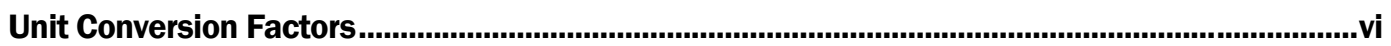

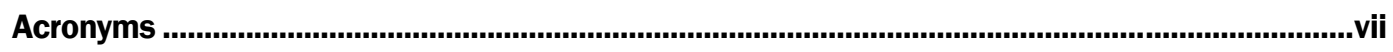

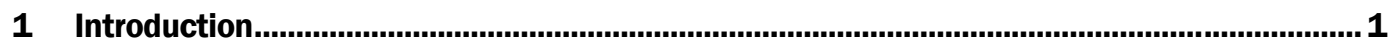

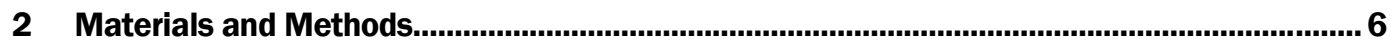

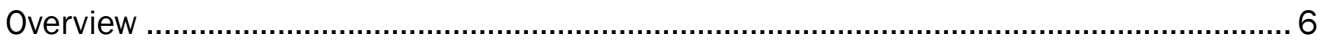

Field Study. Demonstration of False Degradation and the Effect of Acid

Neutralization from a Full-Scale Alkaline Hydrolysis Remediation Project............................. 6

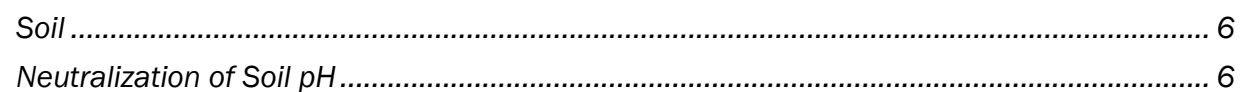

Laboratory Study 1. Confirmation of False Degradation and the Acid

Neutralization Effect ......................................................................................................... 7

Laboratory Study 2. Explosives Dissolution and Development and Testing of Acid

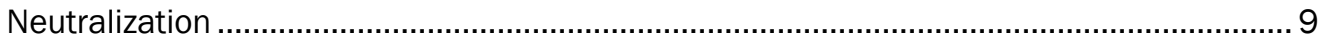

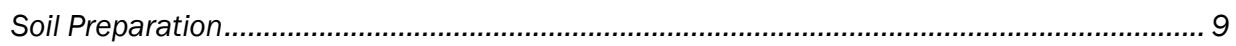

Dissolution of Explosives in Water …….................................................................... 10

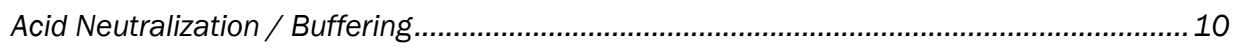

Soil Extraction and Analysis ................................................................................... 11

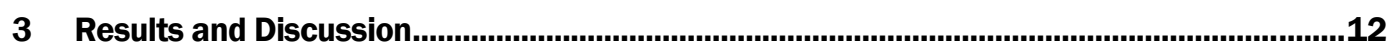

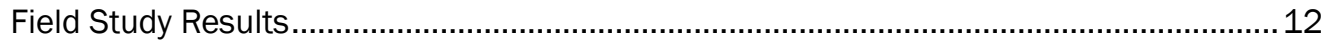

Laboratory Study 1. Confirmation of False Degradation and the Acid

Neutralization Effect .................................................................................................. 12

Laboratory Study 2. Confirmation of False Degradation and the Acid

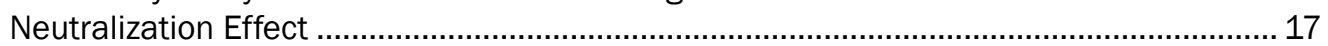

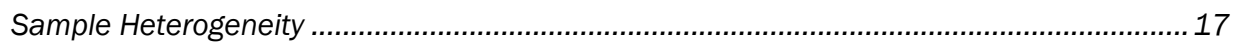

Dissolution of Explosives in Water ....................................................................... 17

Development of Neutralization ................................................................................. 18

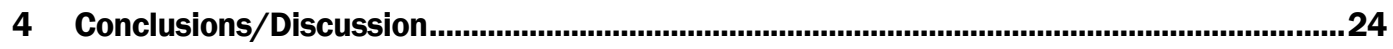

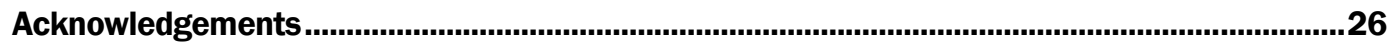

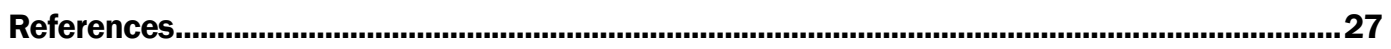

Report Documentation Page 


\section{Figures and Tables}

\section{Figures}

Figure 1. Schematic illustrating the process of alkaline hydrolysis of energetic compounds in soil

Figure 2. Microscale characterization of the process of dissolution of particulate TNT in simulated alkaline pore water (Larson et al. 2008a)

Figure 3. Application of anhydrous pellets of $\mathrm{NaOH}$ for alkaline hydrolysis of soil using a windrow treatment configuration at the former Plum Brook Ordnance Works (PBOW).. 4

Figure 4. Sodium hydroxide pellets visible in soil after initial soil mixing........................................... 7

Figure 5. pH of samples collected from PBOW alkaline hydrolysis remediation project and effect of neutralization.

Figure 6. TNT concentrations of soils collected from the PBOW remediation project, comparing neutralized and non-neutralized samples.

Figure 7. DNT concentrations of soils collected from the PBOW remediation project, comparing neutralized and non-neutralized samples.

Figure 8. Non-linear regression of lime as a variable with $20 \%$ soil moisture. ................................. 14

Figure 9. Variable moisture with 2\% lime addition. ..................................................................... 16

Figure 10. Effect of pre-extraction acidification of soil. ................................................................. 16

Figure 11. Percent of TNT remaining in soil compared to the initial concentration over time as determined by DDI water extraction and analysis by SW-846 Method 8330 .

Figure 12. Percent RDX remaining in soil compared to the initial concentration over time as determined by DDI water extraction and analysis by SW-846 Method 8330 .

Figure 13. Initial average RDX concentration $(\mathrm{mg} / \mathrm{kg}$ ) compared to concentration immediately following $(0.25-\mathrm{hr})$ alkaline hydrolysis with sample neutralization for soils from $L O O W$ and $C E(n=3)$. Error bars are one standard deviation.

Figure 14. Average concentration of RDX in soil initially and after treatment with $\mathrm{NaOH}$ and neutralization $(\mathrm{mg} / \mathrm{kg}, \mathrm{n}=3)$.

Figure 15. Average concentration of TNT in soils initially and after treatment with $\mathrm{NaOH}$ and neutralization, where Limed and Neutralized (1) entails neutralization using buffer only and Limed and Neutralized (2) entails neutralization using buffer and strong acid. $(\mathrm{mg} / \mathrm{kg}, \mathrm{n}=3$ ).

\section{Tables}

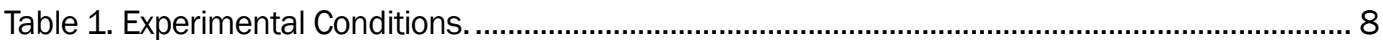

Table 2. Soils used in the dissolution/desorption and neutralization experiments. ......................... 9

Table 3. Initial concentration of TNT and RDX in sample soils as determined using SW-

846 Method 8330.

Table 4. Recommended $\mathrm{pH}$ adjustment protocol for various contaminant mixtures and $\mathrm{AH}$ reagents. 


\section{Preface}

The work reported herein was conducted at the U.S. Army Engineer Research and Development Center (ERDC), Vicksburg, MS. Funding for the work described herein was provided by the Innovative Technology Advocate of the Formerly Used Defense Sites Program, which is managed by Sam Bass, United States Army Corps of Engineers.

Dr. Steven L. Larson, Deborah R. Felt, Scott Waisner, and Dr. Victor Medina of the ERDC Environmental Laboratory (EL), Vicksburg, MS; Catherine C. Nestler of Applied Research Associates, Inc. (ARA), Vicksburg, MS; and Charles Coyle of USACE Center of Expertise, Omaha $\mathrm{NE}$, prepared this report. In-house review was provided by Anthony Bednar and Roy Wade.

This study was conducted under the direct supervision of W. Andy Martin, Branch Chief, Environmental Engineering Branch (EP-E); and Warren P. Lorentz, Division Chief, Environmental Processes and Engineering Division (EPED); and under the general supervision of Dr. Elizabeth Ferguson, Technical Director (EL).

At the time of publication of this report, Dr. Beth Fleming was the EL Director, COL Kevin J. Wilson was Commander of ERDC, and Dr. Jeffery P. Holland was Director of ERDC.

The correct citation for this document is:

Larson, S. L., D. R. Felt, S. Waisner, C. C. Nestler, C. G. Coyle and V. F. Medina. 2012. The Effect of Acid Neutralization on Analytical Results using SW846 Method 8330 on Samples from the Alkaline Hydrolysis of Explosives in Soil. ERDC/EL TR-12-14. Vicksburg, MS: U.S. Army Engineer Research and Development Center. 


\section{Unit Conversion Factors}

\begin{tabular}{|c|c|c|}
\hline Multiply & By & To Obtain \\
\hline Acres & $4,046.873$ & square meters \\
\hline acre-feet & $1,233.5$ & cubic meters \\
\hline cubic feet & 0.02831685 & cubic meters \\
\hline cubic inches & 1.6387064 E-05 & cubic meters \\
\hline cubic yards & 0.7645549 & cubic meters \\
\hline degrees Fahrenheit & $(F-32) / 1.8$ & degrees Celsius \\
\hline Feet & 0.3048 & meters \\
\hline gallons (U.S. liquid) & 3.785412 E-03 & cubic meters \\
\hline Hectares & $1.0 \mathrm{E}+04$ & square meters \\
\hline Inches & 0.0254 & meters \\
\hline Microns & $1.0 \mathrm{E}-06$ & meters \\
\hline miles (U.S. statute) & $1,609.347$ & meters \\
\hline pounds (mass) & 0.45359237 & kilograms \\
\hline pounds (mass) per cubic foot & 16.01846 & kilograms per cubic meter \\
\hline pounds (mass) per cubic inch & $2.757990 \mathrm{E}+04$ & kilograms per cubic meter \\
\hline pounds (mass) per square foot & 4.882428 & kilograms per square meter \\
\hline pounds (mass) per square yard & 0.542492 & kilograms per square meter \\
\hline square feet & 0.09290304 & square meters \\
\hline square inches & 6.4516 E-04 & square meters \\
\hline square miles & $2.589998 \mathrm{E}+06$ & square meters \\
\hline square yards & 0.8361274 & square meters \\
\hline tons (long) per cubic yard & $1,328.939$ & kilograms per cubic meter \\
\hline tons ( 2,000 pounds, mass) & 907.1847 & kilograms \\
\hline tons $(2,000$ pounds, mass) per square foot & $9,764.856$ & kilograms per square meter \\
\hline Yards & 0.9144 & meters \\
\hline
\end{tabular}




\section{Acronyms}

$\begin{array}{ll}\text { ACN } & \text { Acetonitrile } \\ \text { AES } & \text { Atomic Emission Spectrometry } \\ \text { AH } & \text { Alkaline hydrolysis } \\ \text { ANOVA } & \text { Analysis of Varience } \\ \text { CE } & \text { Camp Edwards } \\ \text { DI } & \text { Deionized water } \\ \text { DOD } & \text { Department of Defense } \\ \text { EL } & \text { Environmental Laboratory } \\ \text { EPA } & \text { Environmental Protection Agency } \\ \text { ERDC } & \text { Engineer Research and Development Center } \\ \text { FUDS } & \text { Formerly Used Defense Sites } \\ \mathrm{ft} & \text { foot } \\ \mathrm{ft} 3 & \text { cubic foot } \\ \text { g } & \text { gram } \\ \text { HL } & \left.\text { Hydrated lime [see Ca(OH) })_{2}\right] \\ \text { HPLC } & \text { High-performance liquid chromotography } \\ \text { hrs } & \text { hours } \\ \text { IAAP } & \text { Iowa Army Ammunition Plant } \\ \text { ICP } & \text { Inductively Coupled Plasma } \\ \text { L } & \text { Liter } \\ \text { lb } & \text { pound } \\ \end{array}$

LOOW Lake Ontario Ordnance Works

LSAAP Lone Star Army Ammunition Plant

MDL Minimum Detection Limit

mg milligram

min minutes

$\mathrm{m}^{3} \quad$ cubic meter

nd non-detect

PB1 Soil from the Plum Brook Ordnance Works, West Reservoir 2B Area 
PB2 Soil from the Plum Brook Ordnance Works, Pentolite Road Area

PBOW Plum Brook Ordnance Works

$\mathrm{ppb} \quad$ Parts per billion

ppm Parts per million

r Correlation Coefficient

rpm revolutions per minute

$\mathrm{r}^{2} \quad$ Coefficient of Determination

s second

S Standard Deviation

$\mu \mathrm{g} \quad$ microgram

$\mu \mathrm{g} \quad$ micrometer

\section{Energetic Compounds}

ADNT 2,4/2,6-amino-dinitrotoluene

DNB 1,3-dinitrobenzene

DNT 2,4-dinitrotoluene

RDX Hexahydro-1,3,5-trinitro-1,3,5-triazine

TNT 2,4,6-trinitrotoluene

\section{Other Compounds}

$\begin{array}{ll}\mathrm{CaCl} & \text { Calcium Chloride } \\ \mathrm{CaCO}_{3} & \text { Calcium carbonate } \\ \mathrm{Ca}(\mathrm{OH})_{2} & \text { Calcitic hydrated lime } \\ \mathrm{HCOO}- & \text { Formate } \\ \mathrm{HCl} & \text { Hydrochloric acid } \\ \mathrm{H}_{3} \mathrm{PO} & \text { Phosphoric acid } \\ \mathrm{H}_{2} \mathrm{SO}_{4} & \text { Sulfuric acic } \\ \mathrm{NaOH}^{-} & \text {Sodium hydroxide } \\ \mathrm{NaH}_{2} \mathrm{PO}_{4} & \text { Mono-basic form of phosphoric acid or sodium phosphate } \\ \mathrm{NO}_{2}{ }^{-} & \text {Nitrite } \\ \mathrm{OH}^{-} & \text {Hydroxide ion }\end{array}$




\section{Introduction}

Alkaline hydrolysis has been used in several laboratory studies (Österreicher-Cunha et al. 2003; Davis et al. 2006, 2007; Felt et al. 2002; Larson et al. 2008a, Medina et al. 2007) and field demonstrations (Johnson et al. 2010; Larson et al. 2008b; Waisner et al. 2008, Britto et al. 2010, Tetra Tech 2008a) and full-scale remediation (Tetra Tech 2008b, Shaw Environmental 2008) for the treatment of energetic compounds (particularly, 2,4,6-trinitrotoluene (TNT), dinitrotoluene (DNT), and hexahydro1,3,5-trinitro-1,3,5-triazine (RDX)) in soil. Each of these tests demonstrated effective transformation rates in the treated soils, with removals of 90 to $99 \%$. Observed first-order rates were relatively fast in aqueous phase kinetic tests conducted at $\mathrm{pH}>10: 0.23 \mathrm{hr}^{-1}$ for TNT and $0.18 \mathrm{hr}^{-1}$ for RDX. Rates in soils are also reasonable for treatment (TNT half -life of 0.15 days for soil from Camp Guersney and RDX half-life of 0.28 days for soils from both Fort Wainright and Crane Naval Weapons Station). These rates are comparable to those achieved by other treatment approaches, such as bioremediation. Alkaline hydrolysis reactions break down energetic compounds using different chemical pathways from those of the reductive techniques like bioremediation. For example, reaction products, like amino-DNT, produced by TNT bioremediation are often regulated and can accumulate in the soil. Hydrolysis does not form these compounds and appears to lead to ring cleavage, yielding final transformation products like formate, which are easily degraded by soil microorganisms.

The application of alkaline hydrolysis for treatment of soil involves mixing of caustic source material with soil. Two caustic materials have been explored, calcitic hydrated lime $\left(\mathrm{Ca}(\mathrm{OH})_{2}, \mathrm{HL}\right)$ and sodium hydroxide $(\mathrm{NaOH})$. These materials can be applied to soil as pellets or powders, or, in the case of $\mathrm{NaOH}$, dissolved and applied as an aqueous amendment. Treatment can be conducted using a landfarming approach (where caustic materials are plowed, disked, or mixed using a bulldozer blade), in a modified composting scenario (windrows with caustic material addition, turned periodically for mixing), in slurries, or topically applied, with or without mixing, depending on contaminant depth. In fact, flexibility in treatment approaches is an attractive feature of the alkaline hydrolysis technology. 
Destruction of explosives via alkaline hydrolysis actually occurs in soil pore water. When the caustic material is applied to the soil, it will dissolve into any soil pore moisture, elevating the $\mathrm{pH}$ of that water (Figure 1). In order for degradation to occur, the soil-adsorbed contaminant must dissolve and/or desorb from the soil phase and enter the caustic soil pore water (Figure 2). When it does, the contaminant encounters the elevated $\mathrm{pH}$, and becomes susceptible to nucleophillic attack, resulting in reduced explosives concentrations in soil. Figure 2 shows the dissolution process of particulate TNT. Smaller particles are dissolved rapidly; larger particles more slowly. Soil pH is typically reduced over time via several mechanisms, besides reaction with the energetic compunds: reaction with carbonic acid (from the dissolution of carbon dioxide in the atmosphere), buffering by soil minerals, reactions with humic or organic acids, and gradual leaching of the caustic material (Brooks et al. 2003, Larson et al. 2007).

As mentioned above, both $\mathrm{HL}$ and $\mathrm{NaOH}$ have been successfully used as treatment materials, and both materials essentially work the same way - they both dissolve in the soil pore water elevating its $\mathrm{pH}$ to facilitate hydrolysis reactions. However, $\mathrm{HL}$ and $\mathrm{NaOH}$ have some key differences. The amount of

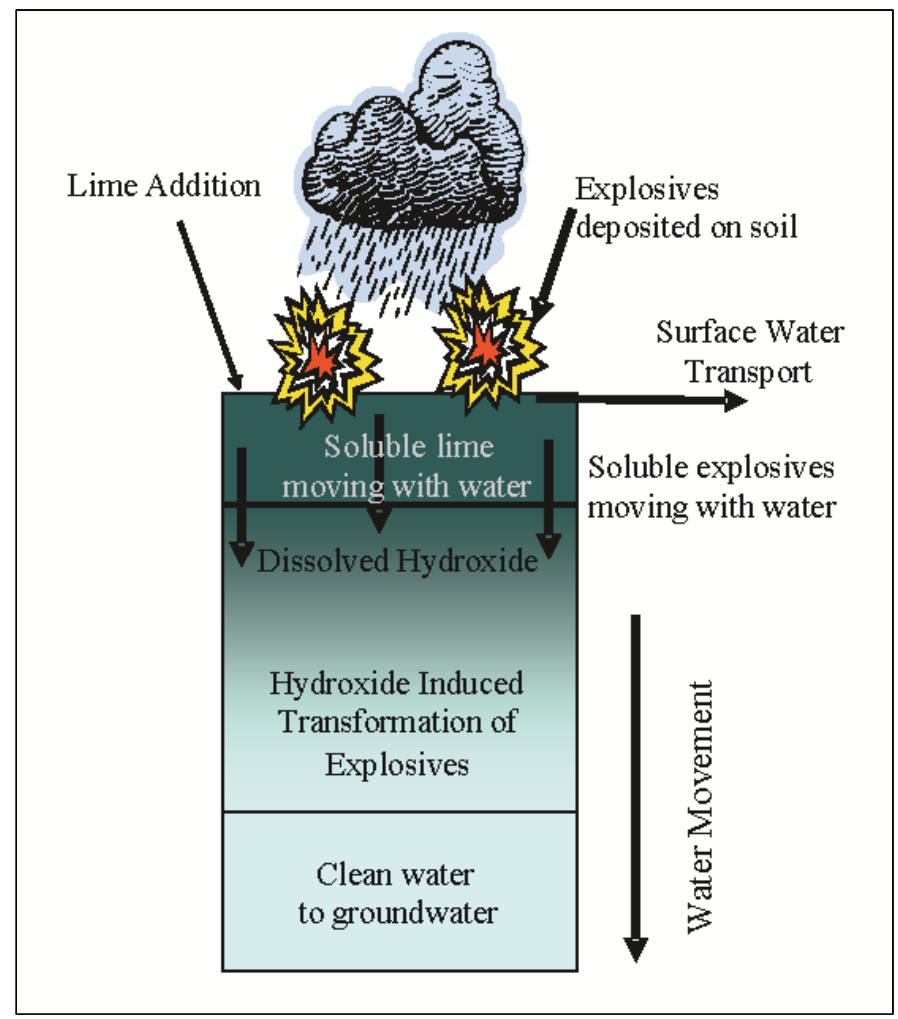

Figure 1. Schematic illustrating the process of alkaline hydrolysis of energetic compounds in soil 

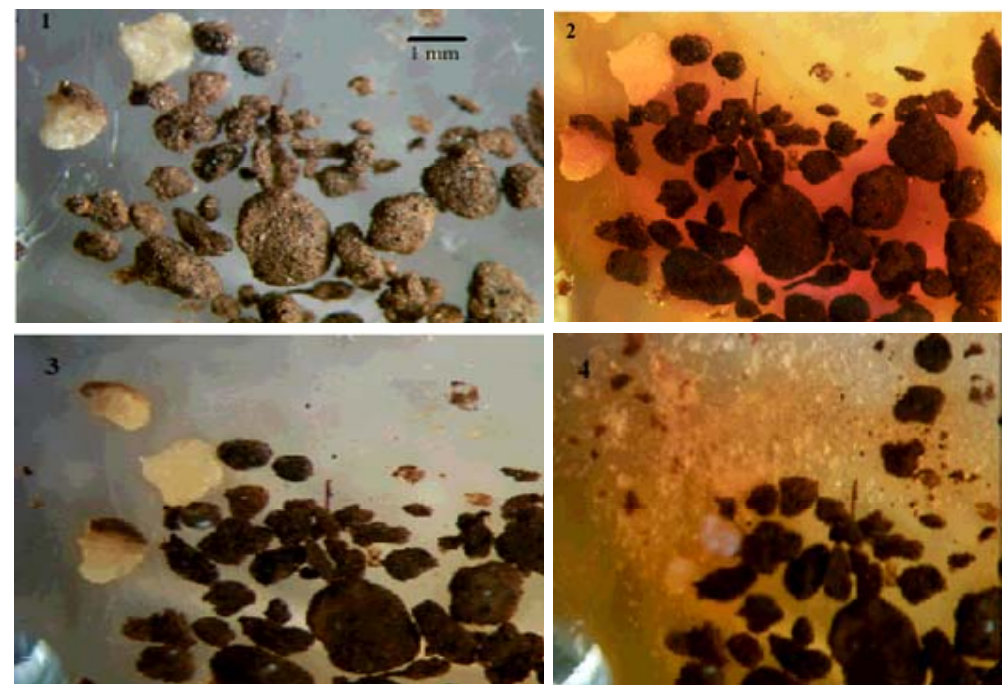

Figure 2. Microscale characterization of the process of dissolution of particulate TNT in simulated alkaline pore water (Larson et al. 2008a)

HL added typically raises $\mathrm{pH}$ of soil pore water to $\mathrm{pH} 10.5$ - 11. Because HL has a limited solubility in water (approximately 1,000 mg/L), the amount of lime used to overcome the buffering capacity of the soil and achieve these $\mathrm{pH}$ levels is far in excess of that which can be solubilized by the maximum amount of moisture that can be retained in the soil. This means that treatment can typically result in a long equilibrium phase. This long equilibrium phase is often beneficial as it maintains the elevated soil pore water $\mathrm{pH}$ over the period required for explosives to dissolve, desorb and react. $\mathrm{NaOH}$ tends to dissociate completely in water, and because of that, $\mathrm{NaOH}$ can increase the soil $\mathrm{pH}$ to over 12, and as high as 14 . Because $\mathrm{NaOH}$ is far more soluble $(>1000 \mathrm{~g} / \mathrm{L})$, if the same mass was applied to a given soil, it will generally dissolve more completely than HL, resulting in a shorter equilibrium phase.

These differences could result in treatment issues. Since $\mathrm{NaOH}$ can achieve a higher $\mathrm{pH}$, it may be able to treat a wider range of contaminants or result in faster reactions. However, the higher $\mathrm{pH}$ could become problematic, as soils with $\mathrm{pHs}$ higher than 12 can be classified as RCRA hazardous wastes. The lower solubility of HL results in a lower $\mathrm{pH}$, but also results in greater persistence of the caustic material. This means that for an identical amount of caustic material added, it is likely that the HL will provide treatment over a longer time frame than the same amount of $\mathrm{NaOH}$. Since the solubility of explosive contaminants can limit the transfer of these compounds into the liquid phase over a given time, this can be an important advantage for HL treatment. 
In spite of the high solubility of $\mathrm{NaOH}$, it is still possible for some of the $\mathrm{NaOH}$ applied during soil remediation to remain undissolved. Although this is generally unlikely, it can occur due to inadequate soil moisture content, and / or inadequate mixing. $\mathrm{NaOH}$ is usually applied in the form of anhydrous pellets and mixed into the soil (Figure 3). If the soil is relatively dry to start with, the water-withdrawing properties of anhydrous amendments can exacerbate the situation by further reducing the moisture content of the soil.
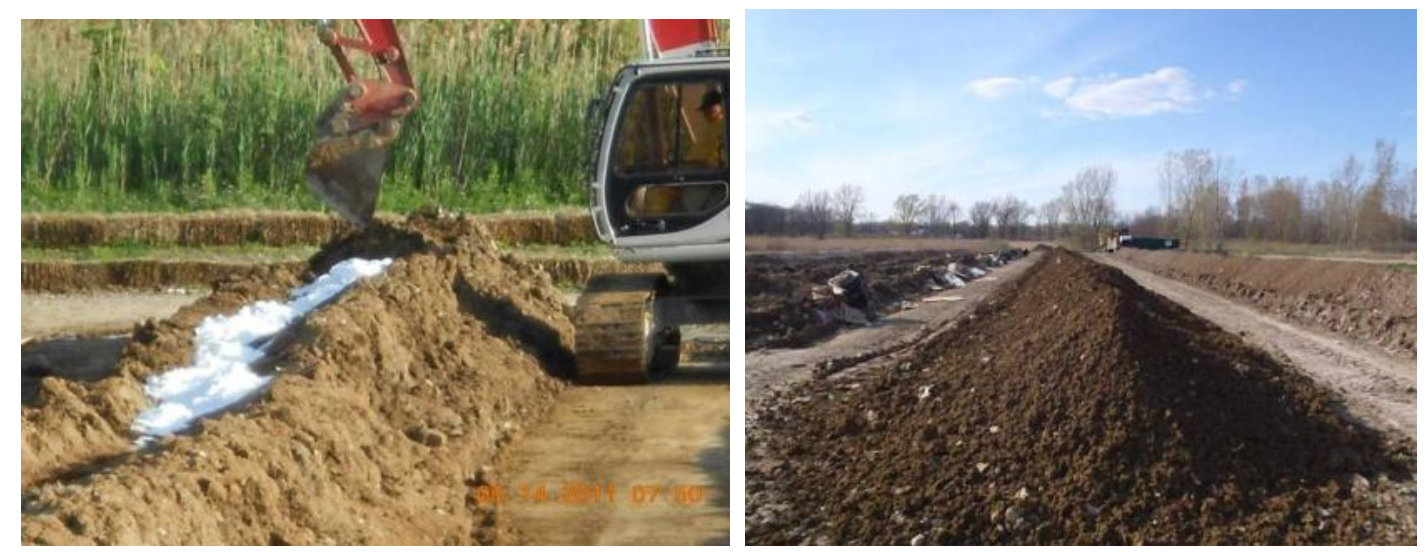

Figure 3. Application of anhydrous pellets of $\mathrm{NaOH}$ for alkaline hydrolysis of soil using a windrow treatment configuration at the former Plum Brook Ordnance Works (PBOW)

Evaluation of any treatment method requires reliable analytical methods. Evaluation of explosives removal is routinely performed using SW-846 Method 8330 (1999). This method was developed before the advent of alkaline hydrolysis treatment, and recent studies have indicated that some errors can occur when this method is applied to alkaline hydrolysis samples. During Method 8330 sample extraction, acetonitrile (ACN) is added to an air-dried soil and the mixture is sonicated for 18 hours. This process results in a portion of the explosives partitioning into the ACN phase. However, since the analytical method calls for air-drying the soil samples prior to extraction, complete drying of the sample is not achieved and residual water can be present in the sample being extracted. This water, which is highly miscible with $\mathrm{ACN}$, exposes the sample being extracted to residual caustic material in solution during the 18 hour sonication, resulting in rapid destruction of the explosive through a similar alkaline hydrolysis process occurring on-site. This can lead to analytical values of explosives concentrations in the soil matrix that are far lower than the actual value of the sampled soil - giving the impression of false degradation. This can adversely affect data quality for post-treatment (i.e., confirmatory) sampling during soil remediation projects. Reviewing data from several studies has shown evidence of this effect, either extremely high contaminant 
transformation rates in the treated soils or very high variability of these rates (Österreicher-Cunha et al. 2003; Davis et al. 2006; Waisner et al. 2008).

In order to resolve the analytical challenges associated with monitoring the actual concentrations of explosives in soil samples during alkaline hydrolysis treatment, a series of comparative studies were performed. Field and laboratory studies were conducted to demonstrate the false degradation phenomena. Then, additional laboratory studies were conducted to develop methods to address this effect. These studies investigated explosives dissolution and desorption from soil into pore water and techniques to neutralize both $\mathrm{HL}$ and $\mathrm{NaOH}$ in soil samples prior to sonication. Universal acid neutralization processes were developed to eliminate the extraction effect, and these can easily be applied to Method 8330 . 


\section{Materials and Methods}

\section{Overview}

The project consisted of three parts. A field study was conducted to demonstrate the issue of false degradation in field-collected samples for a site contaminated with TNT. A second study - a laboratory study - was conducted to confirm the issue of potential false degradation in lime-treated samples for a single soil contaminated with TNT. Finally, a laboratory study was conducted to develop an appropriate acid neutralization method demonstrated with several soil types, two forms of caustic addition (HL and $\mathrm{NaOH}$ ), and for both TNT and RDX.

\section{Field Study. Demonstration of False Degradation and the Effect of Acid Neutralization from a Full-Scale Alkaline Hydrolysis Remediation Project}

Soil

Soil was obtained from an ongoing remediation effort that was conducted in 2011 at the former Plum Brook Ordnance Works (PBOW) located in Sandusky, Ohio. The soils were known to contain both TNT and DNT. The soils were undergoing active alkaline hydrolysis remediation by Tetra Tech, Inc. under the guidance of the Huntington District of the U.S. Army Corps of Engineers. The remediation approach involved excavating the soils and placing them in 9 windrows labeled W1 through W9. In the field, $\mathrm{NaOH}$ was mixed into the soil in a granular form along with a ferric chloride solution. The $\mathrm{NaOH}$ was added at a rate of $2 \%$ on a weight to weight basis. Samples from these 9 windrows were collected at three time periods: T1 was collected at the start of the operation, T2 was about the midpoint of the 6-week treatment, and D was at the end of the 6-week treatment. The intermediate samples (T2) were only collected for the first 3 windrows (W1-W3). Figure 4 shows the initial appearance of dry soil with sodium hydroxide pellets visible after mixing.

\section{Neutralization of Soil pH}

Neutralization of soil $\mathrm{pH}$ prior to extraction was accomplished by placing approximately 20 grams of soil in a plastic pan and adding $20-\mathrm{mL}$ of acid (two different acids were used, and are described below). The resulting soil 


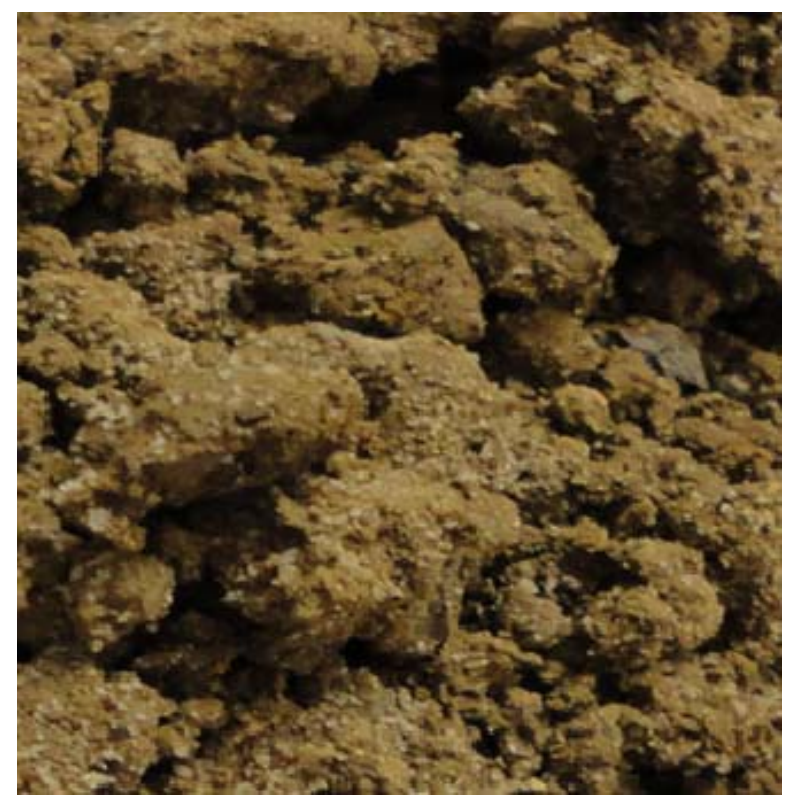

Figure 4. Sodium hydroxide pellets visible in soil after initial soil mixing.

slurry was periodically mixed with a metal spatula until ebullition of gas from the slurry was insignificant. $6.15-\mathrm{N} \mathrm{HCl}$ was used for neutralization. However, after $\mathrm{pH}$ values significantly below 4 were measured in some samples, the acid used was switched, and 20-mL of 5-M sodium phosphate $\left(\mathrm{NaH}_{2} \mathrm{PO}_{4}\right)$ was added to soil samples. After neutralization was completed, the soil sample was mixed in the pan and appropriate amounts were collected for SW-846 Method 8330 extraction and $\mathrm{pH}$ and moisture content analysis.

\section{Laboratory Study 1. Confirmation of False Degradation and the Acid Neutralization Effect}

A total of nine test conditions were established to explore the false degradation effect in a laboratory setting. The test conditions included four levels of lime addition, four levels of soil moisture, and two conditions with pre-extraction acidification. Two of these conditions were controls without lime addition: condition A followed a normal extraction procedure, and condition I was acidified prior to the extraction procedure to determine whether acidification produced any significant impact on extraction or analysis.

Tests were conducted in triplicate with a well-homogenized air-dry soil ( soil moisture $=1.52 \%$, Standard Deviation $(\mathrm{S})=0.004 \%, \mathrm{n}=3$ ) from a site contaminated with high levels of TNT (Plum Brook Reservoir 2B Burn 
Area). Tests were conducted in 50-mL polypropylene centrifuge tubes. 15$\mathrm{g}$ samples of the soil were placed in each test tube. Lime was added to tubes according to the conditions described in Table 1 and mixed in with a spatula. Tubes with lime were then placed on a laboratory rotator, turning at approximately $20 \mathrm{rpm}$ for 30 minutes to allow the lime to mix into the soil. Deionized water (DI) was then added to each tube according to the conditions described in Table 1 and mixed into the soil with a spatula. For all conditions except $\mathrm{C}$ and I, approximately 10-g moist soil was removed from the test tube and placed in a $40-\mathrm{mL}$ amber-glass vial with $20-\mathrm{mL}$ of $\mathrm{ACN}$, and the vials were placed in a sonicating water bath for 18 hours. $\mathrm{ACN}$ was added to each vial within 10 minutes of DI addition. The remaining soil was used for moisture content analysis.

Table 1. Experimental Conditions.

\begin{tabular}{|l|l|l|l|l|l|}
\hline Condition & Moisture & DI & Lime & Lime & Acidified \\
\hline A & $21.5 \%$ & $3.00 \mathrm{~mL}$ & $0 \%$ & $0.00 \mathrm{~g}$ & \\
\hline B & $21.5 \%$ & $3.00 \mathrm{~mL}$ & $2 \%$ & $0.30 \mathrm{~g}$ & \\
\hline C & $21.5 \%$ & $3.00 \mathrm{~mL}$ & $2 \%$ & $0.30 \mathrm{~g}$ & $\mathrm{X}$ \\
\hline $\mathrm{D}$ & $11.5 \%$ & $1.50 \mathrm{~mL}$ & $2 \%$ & $0.30 \mathrm{~g}$ & \\
\hline $\mathrm{E}$ & $6.5 \%$ & $0.75 \mathrm{~mL}$ & $2 \%$ & $0.30 \mathrm{~g}$ & \\
\hline $\mathrm{F}$ & $1.5 \%$ & $0.00 \mathrm{~mL}$ & $2 \%$ & $0.30 \mathrm{~g}$ & \\
\hline $\mathrm{G}$ & $21.5 \%$ & $3.00 \mathrm{~mL}$ & $4 \%$ & $0.60 \mathrm{~g}$ & \\
\hline $\mathrm{H}$ & $21.5 \%$ & $3.00 \mathrm{~mL}$ & $1 \%$ & $0.15 \mathrm{~g}$ & \\
\hline $\mathrm{I}$ & $21.5 \%$ & $3.00 \mathrm{~mL}$ & $0 \%$ & $0.00 \mathrm{~g}$ & $\mathrm{X}$ \\
\hline
\end{tabular}

For conditions $\mathrm{C}$ and I, $10-\mathrm{mL}$ of $2.5-\mathrm{N}$ sulfuric acid $\left(\mathrm{H}_{2} \mathrm{SO}_{4}\right)$ was added following mixing of lime into the soil. The test tubes were hand agitated for approximately 30 seconds and placed on a rotator for approximately 2 hours. Test tubes were vented at approximately 15-minute intervals to relieve gas pressure due to the reactions. The test tubes were then centrifuged at a relative centrifugal force of 2500-g for 15 minutes. The supernatant was withdrawn for explosives analysis and the volume was recorded. At this point, the soil in these conditions was handled in a manner identical to all other conditions.

Following sonication, $5 \mathrm{~mL}$ of extract was withdrawn from each vial and placed in 20-mL glass vials with $5 \mathrm{~mL} \mathrm{0.5 \%} \mathrm{CaCl} \mathrm{solution.} \mathrm{The} \mathrm{vials} \mathrm{were}$ vortexed and allowed to settle for 15 minutes. Four $\mathrm{mL}$ of the mixture was 
filtered through $0.45-\mu \mathrm{m}$ glass-fiber filters into amber sample vials and refrigerated until analyzed.

TNT analyses were conducted by high performance liquid chromatography (HPLC) with a $\mathrm{C}-18$ column and 50:50 water:methanol carrier solution.

\section{Laboratory Study 2. Explosives Dissolution and Development and Testing of Acid Neutralization}

\section{Soil Preparation}

A series of soils with a wide range of soil properties, explosives concentrations, and contaminant/soil weathering were selected so those conducting this study would gain a better understanding of the rate of explosives dissolution/desorption in water. The varied nature of the soils also enabled study participants to more easily develop an effective neutralization technique. The 6 soils came from 5 separate locations and were historically contaminated with explosives as a result of both ordnance use and production activities. Table 2 lists the soils used and the abbreviations that will be used to identify these soils throughout the remainder of the report.

Table 2. Soils used in the dissolution/desorption and neutralization experiments.

\begin{tabular}{|l|l|l|l|}
\hline Name & Sample ID & Soil type & pH \\
\hline Plum Brook 1 (West Reservoir 2B area) & PB1 & Medium sand with clay & 7.9 \\
\hline $\begin{array}{l}\text { Plum Brook 2 } \\
\text { (Pentolite Road Area) }\end{array}$ & PB2 & Medium sand with silt and clay & 8.4 \\
\hline Lake Ontario Ordnance Works & LOOW & Coarse sand/loam & 7.7 \\
\hline Camp Edwards & CE & Sandy silt & 4.9 \\
\hline lowa Army Ammunition Plant & IAAP & Silty clay & 8.1 \\
\hline Lone Star Army Ammunition Plant & LSAAP & Medium sand & 8.0 \\
\hline
\end{tabular}

Each soil sample (Table 2) was spread onto stainless steel trays to a thickness of one half centimeter and allowed to dry in an environmental chamber at $55^{\circ} \mathrm{C}$ over a period of 5 days and nights, as specified by EPA method 8330. After that period, the samples were evaluated for obvious moisture and determined to be dry under the operational definition associated with SW-846 Method 8330.

The samples were ground using a mortar and pestle in batches weighing less than 50 grams in order to reduce particle size and provide a representative sample from which sub-sampling could be reliably achieved. 
This operation was performed behind a laboratory shield under a ventilated fume hood.

Once ground, the samples were passed though a \#200 soil sieve which passes particles smaller than $0.075 \mathrm{~mm}$. Oversize materials, such as rocks or vegetative materials, were removed from the sample.

\section{Dissolution of Explosives in Water}

In order to evaluate the rate of migration of explosives from the solid phase to the dissolved phase, a series of kinetic experiments were performed in 20-ml amber vials. These involved 4 soils (IAAP, CE, LOOW and PB1), investigating the dissolution of TNT and RDX. Two (2) grams of soil and $10 \mathrm{mls}$ of water were allowed to mix and $5 \mathrm{mls}$ of water was periodically removed, filtered, and analyzed in order to determine the amount of explosives that transitioned from the solid to the liquid phase. After each $5 \mathrm{ml}$ removal, an additional $5 \mathrm{mls}$ of deionized water was added to the sample to return the total volume to $10 \mathrm{mls}$.

\section{Acid Neutralization / Buffering}

The dosing level for the alkaline hydrolysis material was $10 \%$ by soil dry weight. These soils were allowed to air dry and water content was between 3 and $5 \%$. The $\mathrm{NaOH}$ dosing rate was calculated by determining the same number of $\mathrm{OH}$ - equivalents as $10 \% \mathrm{HL}$. There are 2 moles of HL for each mole of $\mathrm{NaOH}$.

Two separate neutralization studies were performed. The first study used a stoichiometric equivalent of the mono-basic form of phosphoric acid $\left(\mathrm{NaH}_{2} \mathrm{PO}_{4}\right)$ in order to attempt to neutralize both $\mathrm{HL}$ and $\mathrm{NaOH}$ caustic reagents prior to sample drying, addition of $\mathrm{ACN}$, sonication, sample preparation, and analysis. At set periods of time following addition of the caustic agent, an aqueous solution containing one equivalent of the $\mathrm{NaH}_{2} \mathrm{PO}_{4}$ was added to the sample, and mixed thoroughly. The sample was then allowed to air-dry for 7 days. The dried sample was extracted using ACN and sonicated for 18 hours prior to analysis.

The second neutralization study used a combination of mono-basic and dibasic phosphoric acid (one equivalent each in neutralization 1, or two equivalents phosphoric acid and one equivalent of $\mathrm{NaH}_{2} \mathrm{PO}_{4}$ in neutralization 2). This study was tailored for the neutralization of samples treated with hydrated lime. 


\section{Soil Extraction and Analysis}

Soil samples were extracted following the procedures outlined in US EPA SW-846 Method 8330 (1999). Two g of air-dried (55C) soil and $10 \mathrm{ml}$ of $\mathrm{ACN}$ were placed in a test tube and the mixture was combined in a Vortex mixer for 1 -min and sonicated in the dark at $5{ }^{\circ} \mathrm{C}$ for $18 \mathrm{hr}$.

The explosives concentrations of the different soils were quantified using a DIONEX HPLC system equipped with a $\mathrm{C}-18$ reverse phase column and a photodiode array detector which measured absorbance at $254 \mathrm{~nm}$. A CN column was used for confirmatory analysis. The mobile phase was 50:50 (v:v) methanol:organic-free reagent water. The flow rate was set at $1.0 \mathrm{ml} / \mathrm{min}$ and a $25 \mu \mathrm{l}$ injection volume was used. The MDL for explosives under these analysis conditions is $0.02 \mathrm{mg} / \mathrm{L}$.

Matrix spikes are an accepted method of quantifying the recovery of the compound of interest guard against false negatives. In a matrix spike, the matrix (soil, groundwater, surface water, etc.) has a spike of the contaminant of interest added to it and is thoroughly mixed. This sample is then extracted and analyzed. The recovery of the spike can be quantified. Matrix spikes are included as part of the EPA Method 8330. Their value is critical in explosives studies, particularly in those involving alkaline hydrolysis. 


\section{Results and Discussion}

\section{Field Study Results}

The measured $\mathrm{pH}$ of soils, both before and after neutralization, is presented in Figure 5. Before neutralization, the $\mathrm{pH}$ of all soils tested was between 12.0 and 13.3. Following neutralization, the $\mathrm{pH}$ of most soils was between 4 and 7. The $\mathrm{pH}$ of samples $\mathrm{W}_{3}-\mathrm{T} 2, \mathrm{~W}_{5}-\mathrm{T} 1, \mathrm{~W} 6-\mathrm{T} 1$, and $\mathrm{W}_{7}-\mathrm{T} 1$ were all below 2, which was lower than the desired range of 4 to 8 . The occurrence of an excessively low $\mathrm{pH}$ in neutralized samples was avoided in future samples by switching the acid used from $\mathrm{HCl}$ to $\mathrm{NaH}_{2} \mathrm{PO}_{4}$. The $\mathrm{pH}$ of samples $\mathrm{W}_{3}-\mathrm{T} 1$ and $\mathrm{W} 4-\mathrm{T} 1$ were not measured.

The results of TNT and DNT analysis of soils by Method 8330 by both the standard extraction method and with $\mathrm{pH}$ neutralization prior to extraction are presented in Figure 6 and Figure 7, respectively. In general, where these compounds were detected, neutralization of the soil $\mathrm{pH}$ prior to extraction resulted in higher concentrations of these compounds being detected. Two exceptions, samples W6-T2 and W7-T2, did occur with TNT. In all cases, the measured values for both TNT and DNT were below the method detection limits by the final samples (-W\#-D).

In all cases, the measured values for both TNT and DNT by the standard extraction method were below the method detection limits by the final samples (-W\#-D). However, DNT was still detectable in the final samples from windrows $\mathrm{W}_{5}$, $\mathrm{W} 6$, and $\mathrm{W}_{7}$ when the $\mathrm{pH}$ of the soil was neutralized prior to extraction. Results obtained by using $\mathrm{pH}$-neutralization of the soil samples prior to extraction also show the progress of explosives destruction during the remediation project.

\section{Laboratory Study 1. Confirmation of False Degradation and the Acid Neutralization Effect}

The field study confirmed that acid neutralization greatly affects the results of an actual field application of alkaline hydrolysis. However, variability in the field samples creates variability in the results that required confirmation by a focused laboratory study. Figure 8 shows the results of a study in which identical soils from the Plum Brook Ordnance Works (Reservior 2B burn area) were sampled right after being treated with different amounts of HL 


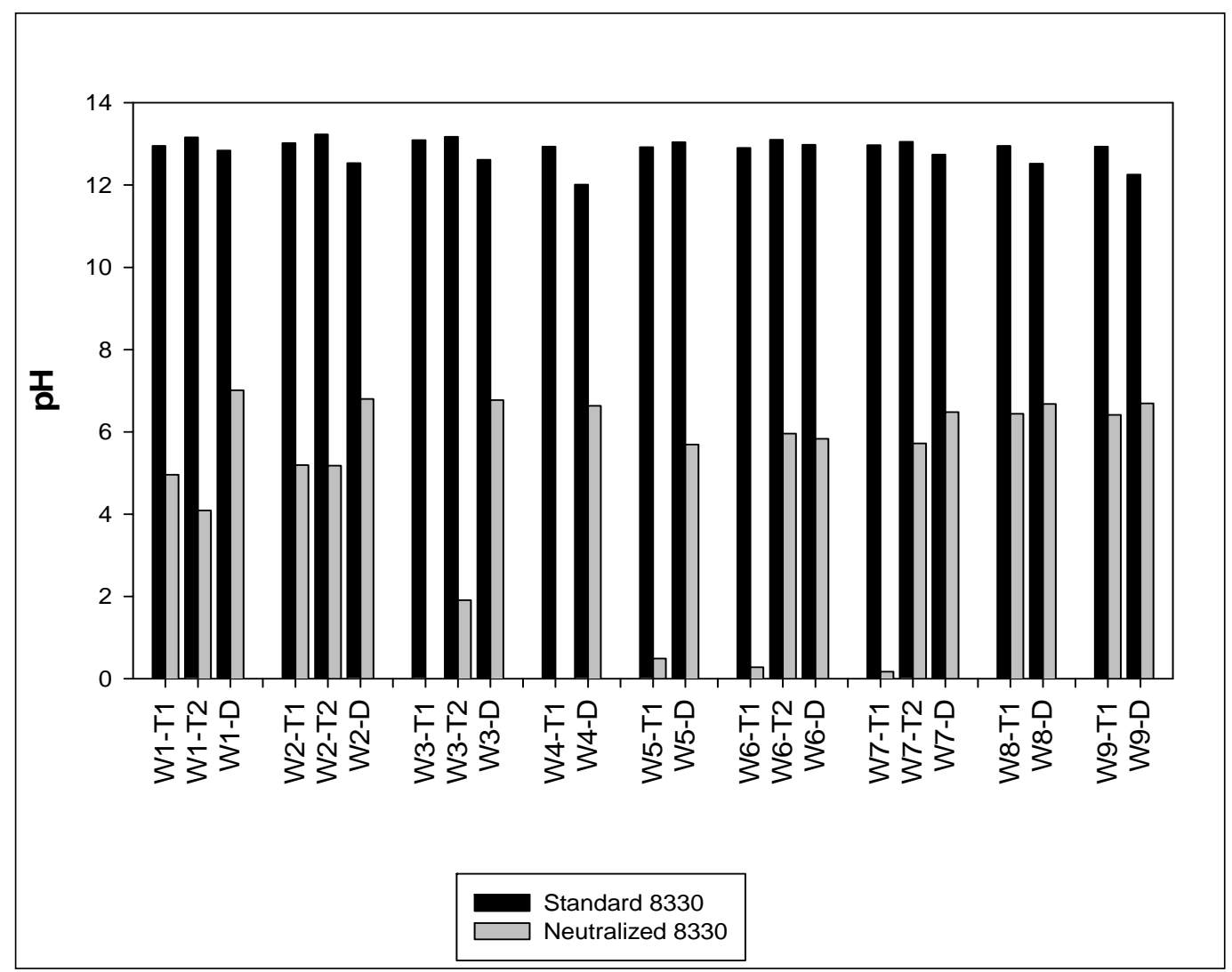

Figure 5. $\mathrm{pH}$ of samples collected from PBOW alkaline hydrolysis remediation project and effect of neutralization.

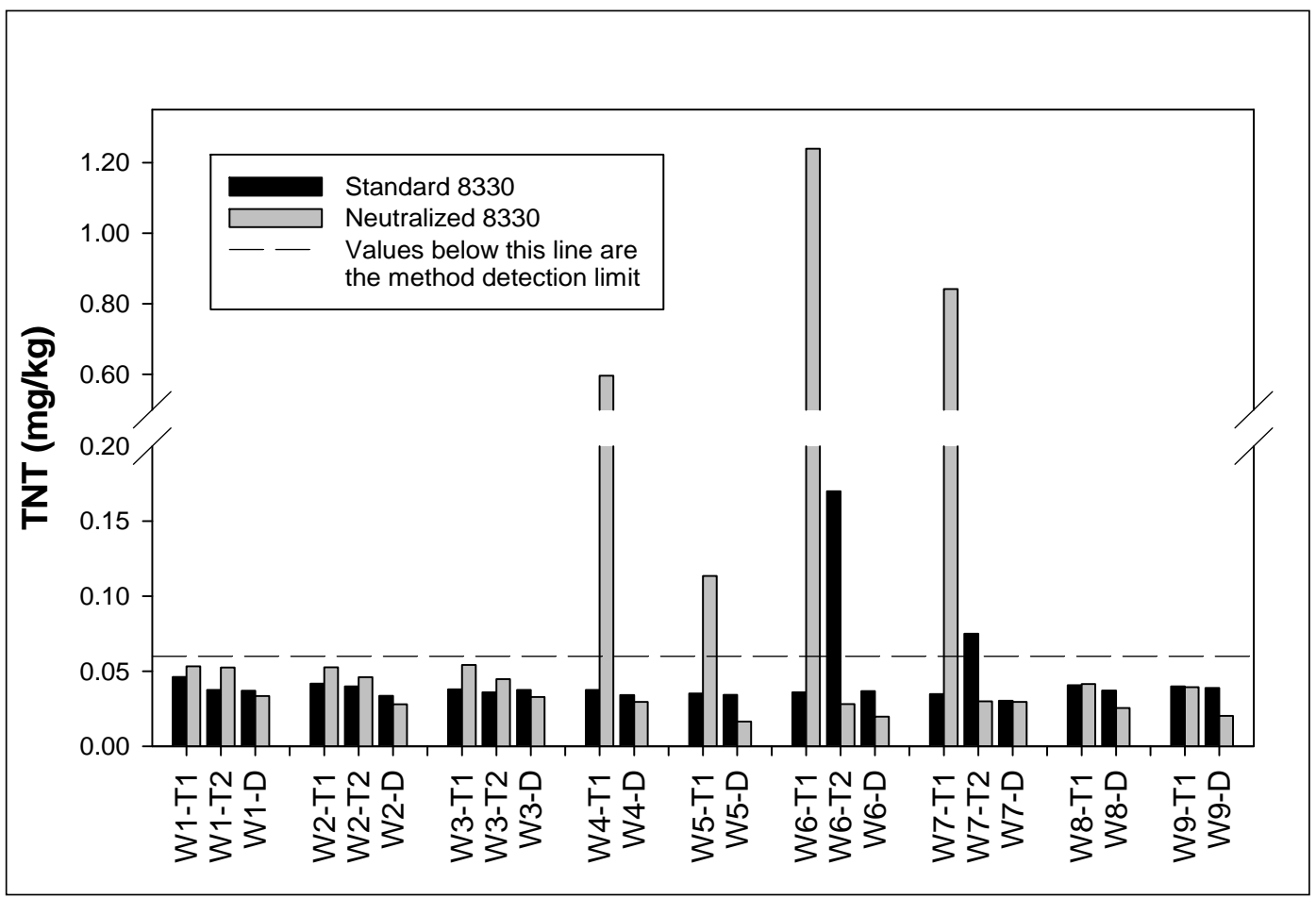

Figure 6. TNT concentrations of soils collected from the PBOW remediation project, comparing neutralized and non-neutralized samples. 


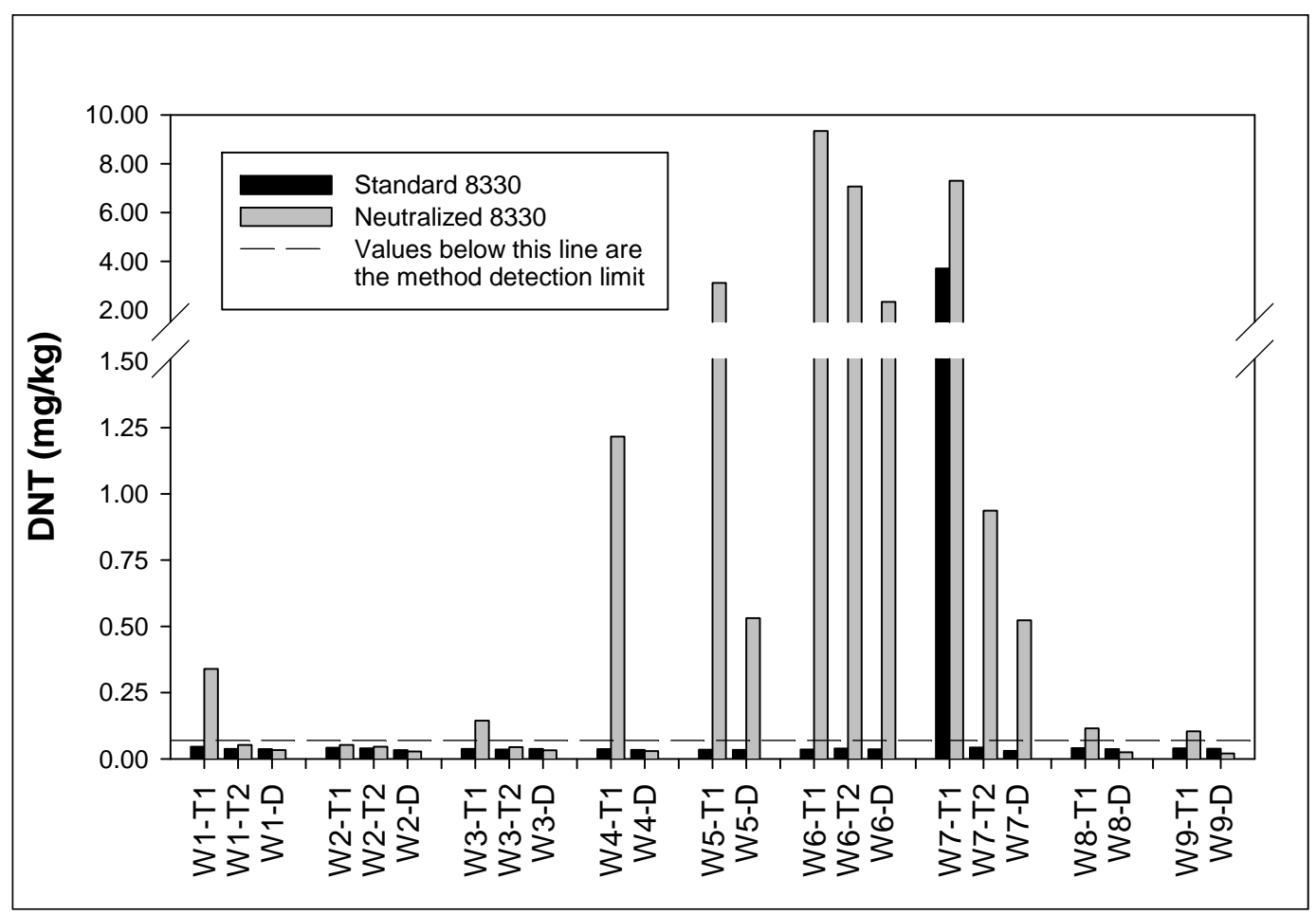

Figure 7. DNT concentrations of soils collected from the PBOW remediation project, comparing neutralized and non-neutralized samples.

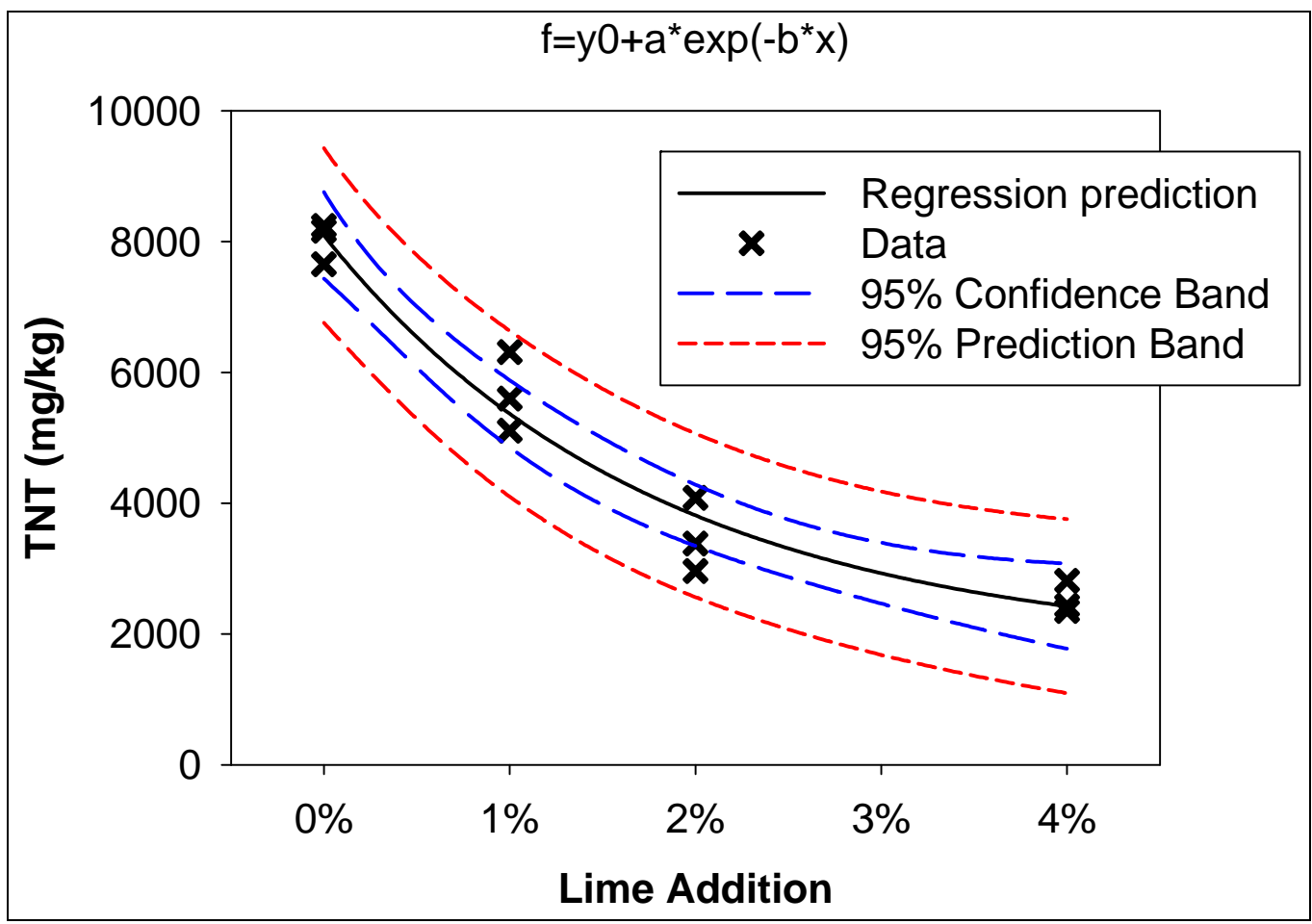

Figure 8 . Non-linear regression of lime as a variable with $20 \%$ soil moisture. 
with $20 \%$ moisture addition. Although the sampling/extraction process was conducted immediately after the addition of HL and water, the HL treated samples had substantially lower levels of TNT measured by the Method 8330 process. This reduction is substantially greater than predicted by the reaction rate of HL treatment.

Analysis of variance (ANOVA with Tukey test) with lime as a variable showed that all conditions were significantly different $(\alpha=0.05)$, with the exception of $2 \%$ lime addition and $4 \%$ lime addition. This is an indication that a significant relationship may exist between the amount of lime added and the results of the TNT extraction/analysis.

An exponential decay regression approaching a minimum was used to describe the data (Figure 8). This regression provided a good fit of the data with an adjusted coefficient of determination $\left(\mathrm{R}^{2}\right.$ adj $)$ of 0.948 . The regression indicates that a minimum concentration of approximately $1760-\mathrm{mg} / \mathrm{kg}$ of TNT is approached with increasing lime addition.

Figure 9 shows the results of a study focusing on the effect of soil moisture on the extraction and analysis of TNT (see Table 1). In this study, soil moisture was varied (o to 20\%) with constant lime addition (2\%). With no moisture, the TNT concentration was close to the level found for no lime addition (see Figure 8, the $0 \%$ lime addition value). However, with just $5 \%$ moisture, the measured TNT concentration was about 50\%. Higher moisture additions resulted in further, although modest, decreases. ANOVA analyses confirmed that the moisture added conditions were statistically lower than the control (no moisture added).

Figure 10 summarizes the effect of water and HL, and how acidification can improve the analytical process. Point $\mathrm{F}$ shows the concentration with no moisture or lime. Point A shows that with moisture alone, no effect is seen. Point D shows no effect with lime, but no moisture. However, Point B shows that with both of these parameters present, the TNT concentration is depressed. Acidification is shown in points $\mathrm{C}$ and $\mathrm{I}$. With $\mathrm{C}$, lime is present. The reported concentration was lower and the concentration between replicates is more variable. However, ANOVA analysis indicates that the concentration is not statistically significant compared to non-limed samples. 


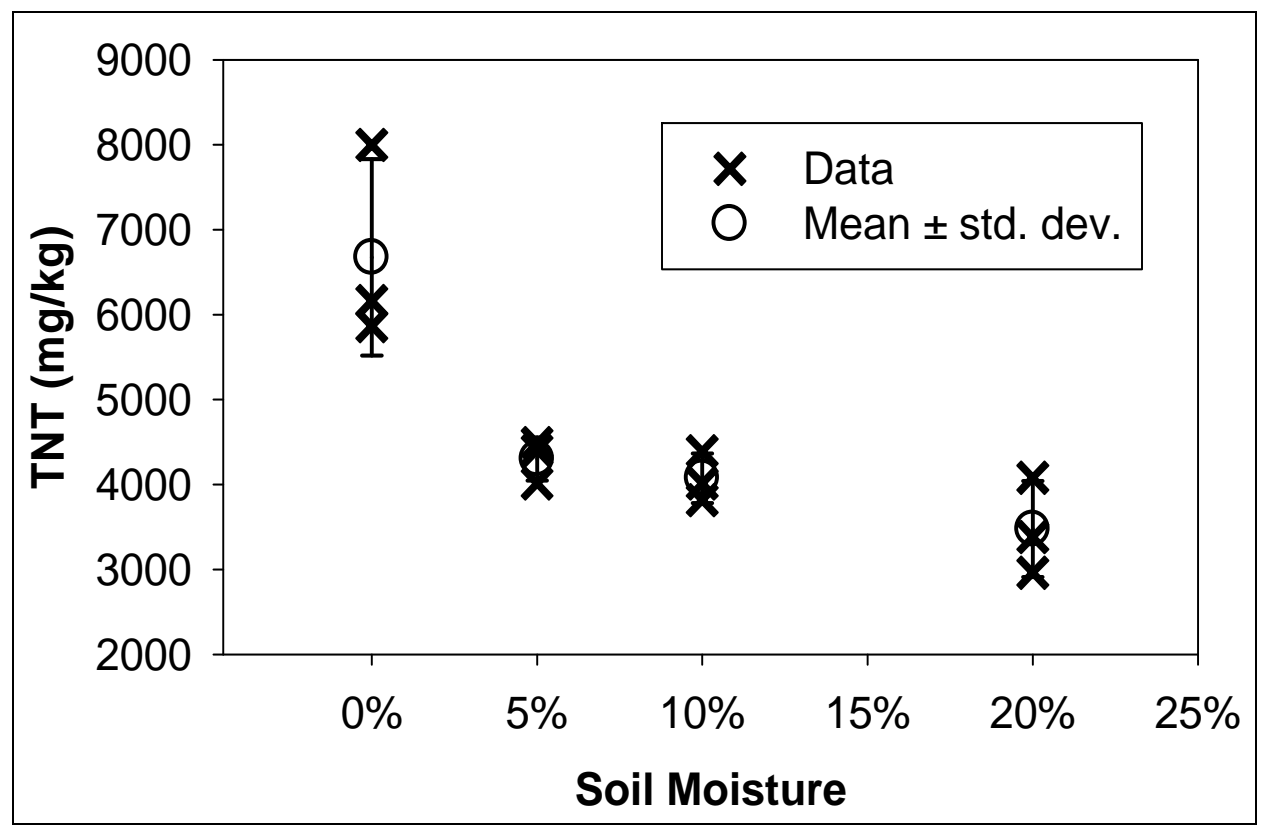

Figure 9 . Variable moisture with $2 \%$ lime addition.

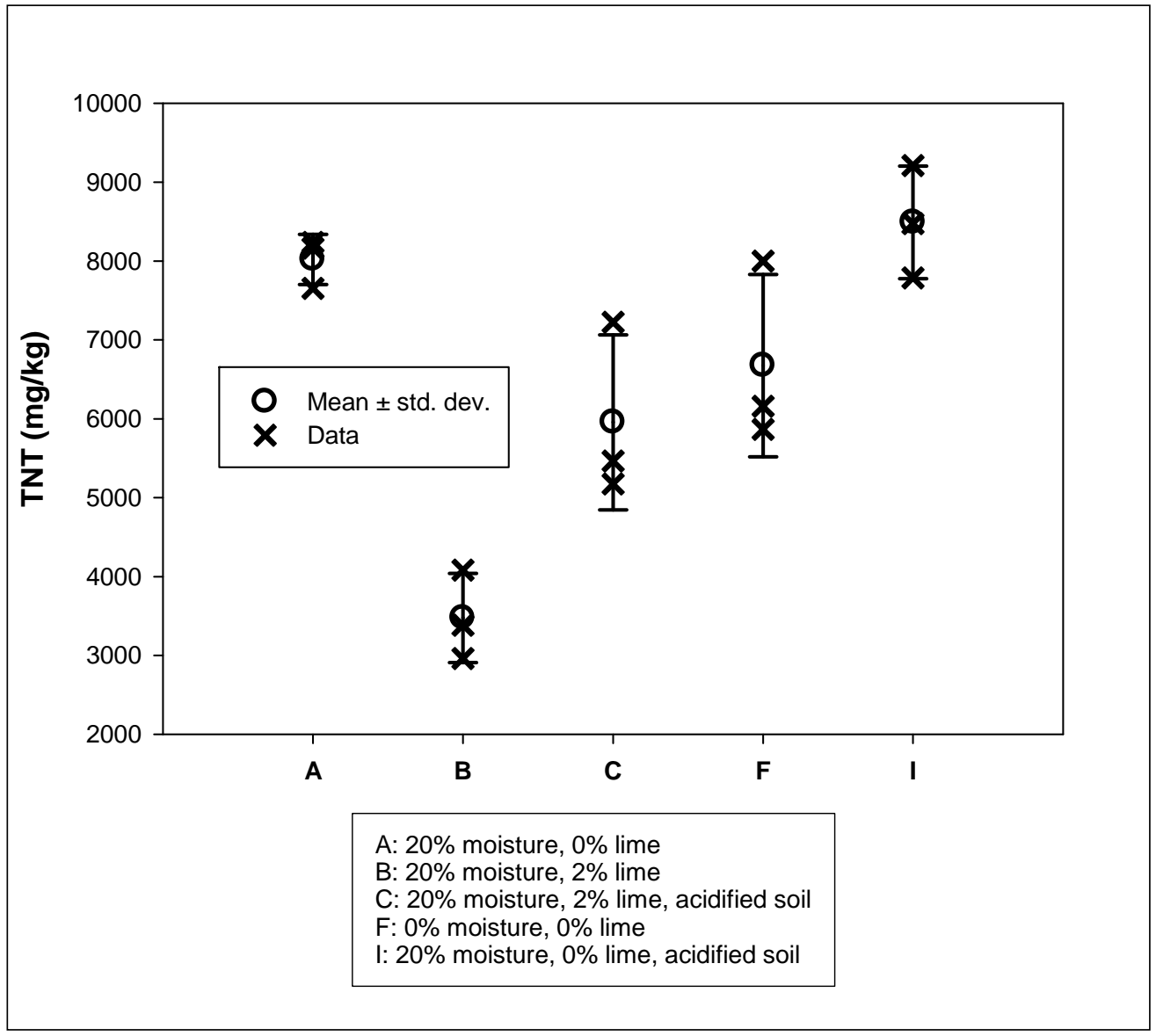

Figure 10. Effect of pre-extraction acidification of soil. 
For this portion of the study, $\mathrm{H}_{2} \mathrm{SO}_{4}$ was used to affect neutralization. The reaction created substantial foaming that took up to 2 hours to dissipate. No effort was made to optimize the neutralization approach. The next portion of the study focused on developing an acidification process that can be universally used for both TNT and RDX, for a variety of possible caustic additions, and for a wide range of soil types.

\section{Laboratory Study 2. Confirmation of False Degradation and the Acid Neutralization Effect}

\section{Sample Heterogeneity}

Based on the results of the initial set of triplicate analyses (Table 2), specific soils were selected for dissolution, alkaline hydrolysis treatment, and neutralization studies. As seen in Table 3, soils with significant concentrations of explosives, either TNT, RDX or both, showed low (10\% or less) standard deviations among the triplicate analyses. Soils that contained explosives at levels close to the detection limit showed higher variability within the triplicate analyses. Soils selected for further investigation of TNT transformation and neutralization techniques are: PB1, LOOW, IAAP and CE. Soils selected for further investigation of RDX transformation and neutralization techniques are: LOOW, CE, and IAAP.

Table 3. Initial concentration of TNT and RDX in sample soils as determined using SW-846 Method 8330.

\begin{tabular}{|c|c|c|c|c|c|c|}
\hline \multirow[b]{2}{*}{ Soil } & \multicolumn{3}{|c|}{$\begin{array}{c}\text { TNT } \\
(\mathrm{mg} / \mathrm{kg})\end{array}$} & \multicolumn{3}{|c|}{$\begin{array}{c}\mathrm{RDX} \\
(\mathrm{mg} / \mathrm{kg})\end{array}$} \\
\hline & AVG & STDEV & \%STDEV & AVG & STDEV & \%STDEV \\
\hline PB1 & \begin{tabular}{|l|}
15.97 \\
\end{tabular} & 0.39 & $2.45 \%$ & ND & - & - \\
\hline PB2 & 0.85 & 0.04 & $4.39 \%$ & ND & - & - \\
\hline LOOW & 510.67 & 54.90 & $10.76 \%$ & 314.67 & 4.07 & $1.29 \%$ \\
\hline CE & 2,655.08 & 50.55 & $1.90 \%$ & 313.85 & 2.98 & $0.95 \%$ \\
\hline IAAP & 0.30 & 0.13 & $43.21 \%$ & 15.97 & 0.39 & $2.45 \%$ \\
\hline LSAAP & 0.51 & 0.06 & $10.76 \%$ & ND & - & - \\
\hline
\end{tabular}

ND - non-detect, below the laboratory detection limit

\section{Dissolution of Explosives in Water}

As described in the Introduction, alkaline hydrolysis (AH) relies on the dissolution of the contaminant (in this case, an explosive) for the destructive reactions to occur. TNT and RDX are the most important explosives used by 
the Army from an environmental standpoint. These compounds have some important differences in terms of solubility that may affect their reactions in an AH system. A series of selected soil extractions were performed with RO water in order to evaluate the rate at which the explosive present either as particulates or bound to the soil particles transferred into the aqueous portion of the system where base hydrolysis can occur. Four soils were analyzed for TNT and RDX (Figures 11 and 12, respectively), with results presented as the percent explosive remaining from the initial mass over time.

As can be seen in Figure 11, the four soils, IAAP, CE, LOOW and PB1 showed similar slow rates of migration of the soil-based TNT into the extraction water over time. After 20 days and four removal/replacements of one half of the extraction water volume, 80 to 90 percent of the TNT in all four soils was still associated with the solid phase. This slow rate of migration from the soil to the dissolved form is a result of the slow rate of dissolution of particulate TNT into water as well as the strong sorptive forces between soil and TNT (Larson et al. 2008a). The preparation of the soils used in the comparative studies involved grinding soils using a mortar and pestle to a point where the soils passed through a $0.075 \mathrm{~mm}$ sieve. Following the grinding and sieving of air-dried soils, no particulate explosive could be observed in any of the soils. From a remediation standpoint, slow dissolution is a primary reason why the $\mathrm{pH}$ of the pore water of a soil being treated using alkaline hydrolysis must remain elevated over an extended period of time.

Figure 12 displays results for the same water extraction experiment for RDX for the three soils IAAP, CE, and LOOW-there was no RDX in PB1. Unlike the results displayed in Figure 8 for TNT, the RDX undergoes a rapid dissolution/desorption from soil when exposed to an excess of distilled water. For all four soils, greater than $50 \%$ of the RDX present in the soil is found dissolved in the water on the first sampling (15 minutes) and at $120 \mathrm{hrs}$, after three water removal replacement cycles, all of the RDX that was initially in the soils is accounted for in the water. Poor soil sorption, as well as rapid dissolution of RDX when aqueous RDX concentrations are low, is a possible explanation for these observations.

\section{Development of Neutralization}

As indicated previously, soil $\mathrm{pH}$ is typically reduced over time following AH treatment. Thus, there can be cases where the neutralization step is not necessary. If, following $\mathrm{AH}$ treatment, the $\mathrm{pH}$ of the soil has fallen 


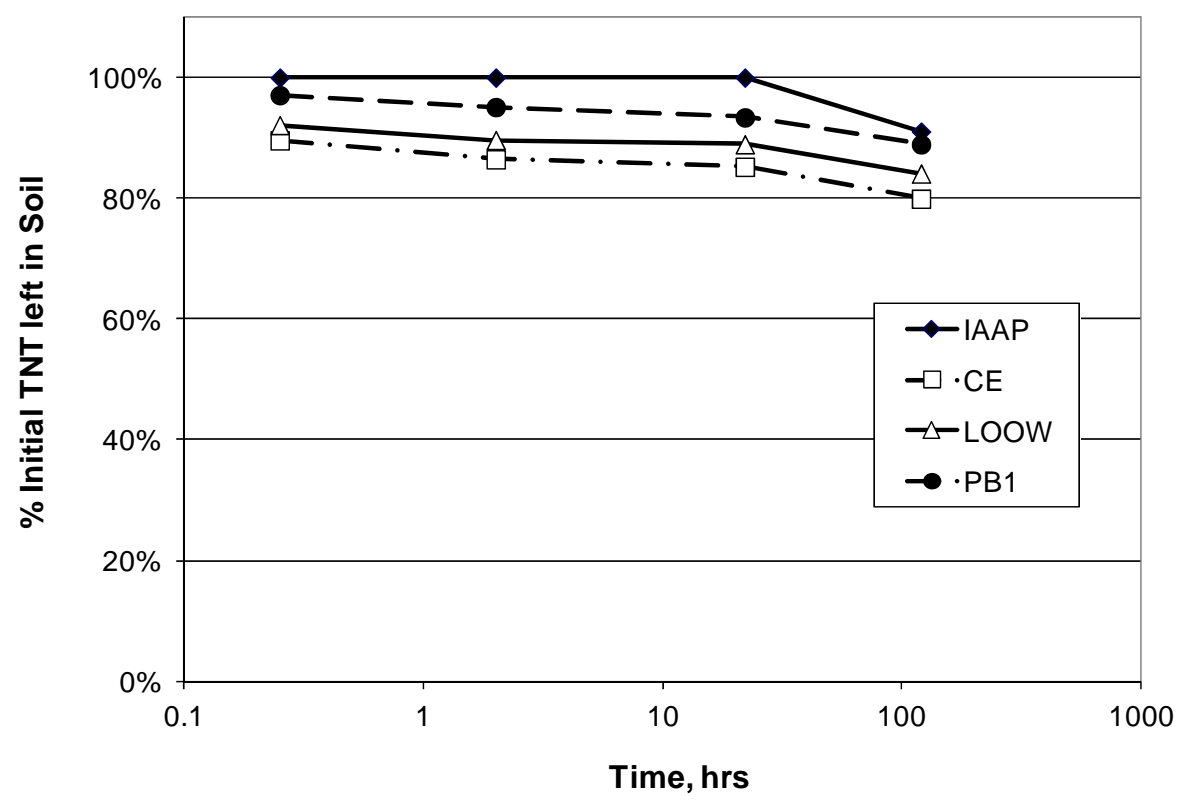

Figure 11. Percent of TNT remaining in soil compared to the initial concentration over time as determined by DDI water extraction and analysis by SW-846 Method 8330 .

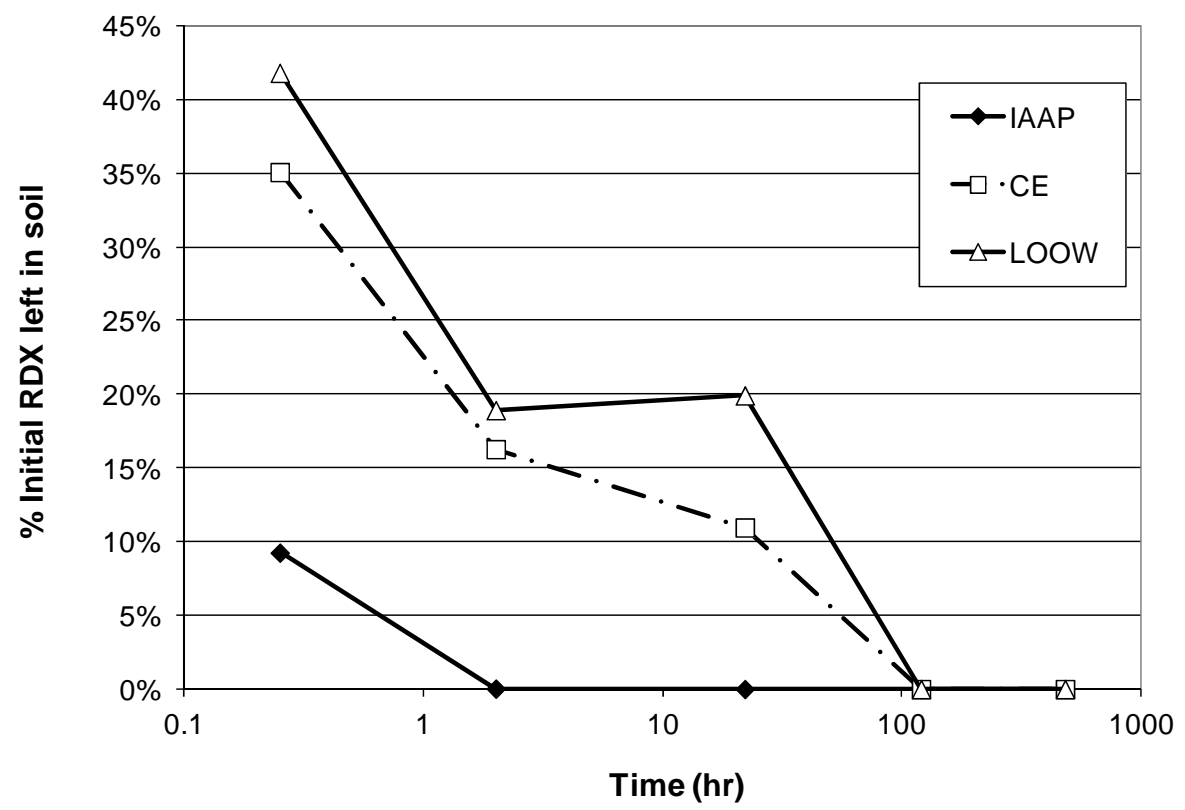

Figure 12. Percent RDX remaining in soil compared to the initial concentration over time as determined by DDI water extraction and analysis by SW-846 Method 8330 . 
below a $\mathrm{pH}$ of 10, or below the background soil $\mathrm{pH}$, the neutralization step may not be necessary. However, the amount of time for the $\mathrm{pH}$ of the soil to fall back to a pH level that would eliminate the need to neutralize is variable, and could range from days to months, depending on site-specific factors. When implementing a soil treatment remedial action, however, there is usually an immediate need (and often contractual requirements) to determine the effectiveness of the treatment process. In addition, early determination of treatment effectiveness is strongly recommended from a quality assurance standpoint. A pro-active approach to confirmatory sampling can oftentimes be used to correct problems, to potentially modify the process to ensure that the technology is being properly implemented, prevent the need to retreat soil, and reduce the potential for costly contract modifications. If lime is being used, it is generally advisable to allow more time for the $\mathrm{AH}$ reaction to occur before collecting confirmatory samples, than if $\mathrm{NaOH}$ is being used.

Remediation projects conducted with high water contents, such as slurrybased treatments, would likely have fewer issues with residual $\mathrm{pH}$, as the high water content would promote mass transfer out of the solid phase. However, due to the fact that the $\mathrm{pH}$ of the entire system must be maintained above 10 to promote the hydrolysis reactions, there would still be potential for false positive degradation results. The acid neutralization approach developed in this study would be appropriate for slurry applications.

\section{Buffer-only Neutralization}

The first neutralization study compared explosives concentrations from LOOW and CE soil. Near immediate ( $15 \mathrm{~min}$ ) neutralization of a $\mathrm{NaOH}$ treated sample using one equivalent of $\mathrm{NaH}_{2} \mathrm{PO}_{4}$ returned a result from EPA Method 8330 analysis for RDX that was, within one standard deviation, identical to the analysis of a sample that was not treated with $\mathrm{NaOH}$ (Figure 13). When HL was used as the AH agent, however, neutralization was not effective at returning an RDX concentration that reflected the true concentration of RDX at the time of neutralization. For both LOOW and CE, less than 50\% recovery was observed following neutralization (Figure 10).

Because $\mathrm{NaOH}$ is a strong base that is highly soluble in water, there appears to be a rapid reaction between the $\mathrm{NaH}_{2} \mathrm{PO}_{4}$ and the dissolved $\mathrm{NaOH}$, reducing the system $\mathrm{pH}$ to below the $\mathrm{pH}$ at which $\mathrm{AH}$ of $\mathrm{RDX}$ occurs. $\mathrm{HL}$, 


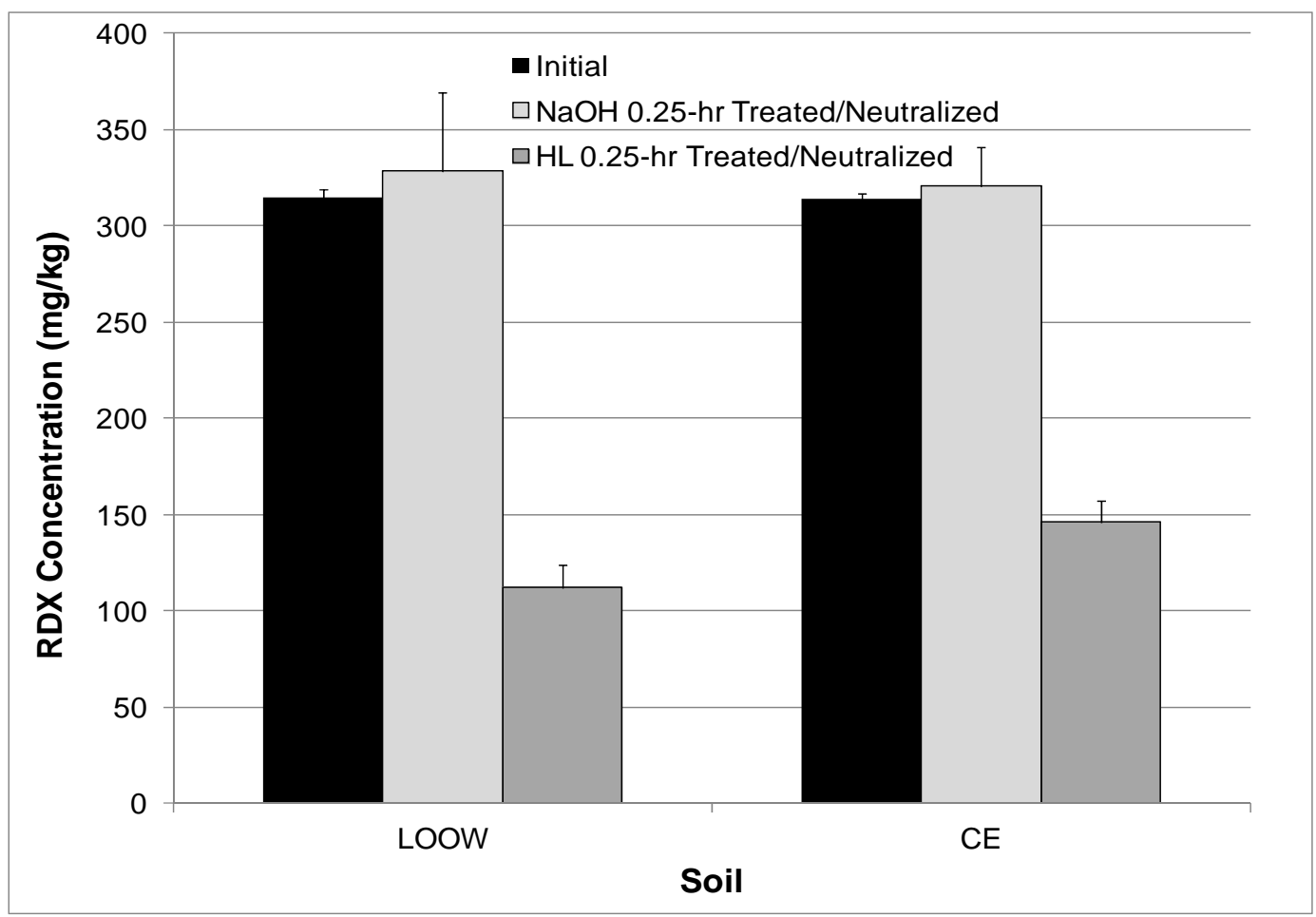

Figure 13. Initial average RDX concentration $(\mathrm{mg} / \mathrm{kg}$ ) compared to concentration immediately following (0.25-hr) alkaline hydrolysis with sample neutralization for soils from LOOW and CE $(n=3)$. Error bars are one standard deviation.

on the other hand, dissolves more slowly, releasing hydroxide ions over a greater span of time. Even though there was sufficient $\mathrm{NaH}_{2} \mathrm{PO}_{4}$ in the system to neutralize the excess hydroxide ion, the hydroxide ions slowly and continuously enter the aqueous portion of the system. Localized areas of high $\mathrm{pH}$ pore water occur throughout the soil surrounding the lime particles. These areas are long-lived enough, due to the low solubility of HL, to continue degrading RDX. In summary, the slow reaction rate between HL and the buffer-only system does not prevent the AH reaction from occurring during the analytical procedure.

\section{Buffer-Acid Neutralization}

In order to provide a more universal neutralization procedure for soils that have been amended with either $\mathrm{NaOH}$ or $\mathrm{HL}$, a strong acid (in the present studies, that was phosphoric acid $\left.\left(\mathrm{H}_{3} \mathrm{PO}_{4}\right)\right)$ must be incorporated into the neutralization system. The acid can rapidly dissolve the HL along with the $\mathrm{NaH}_{2} \mathrm{PO}_{4}$ buffer that is required in order to keep the sample from becoming too acidic for analysis. Figure 14 shows the results of initial RDX concentrations, and RDX concentrations obtained using buffer only (Limed and Neutralized -1) or using using buffer and strong acid (Limed and Neutralized -2). 


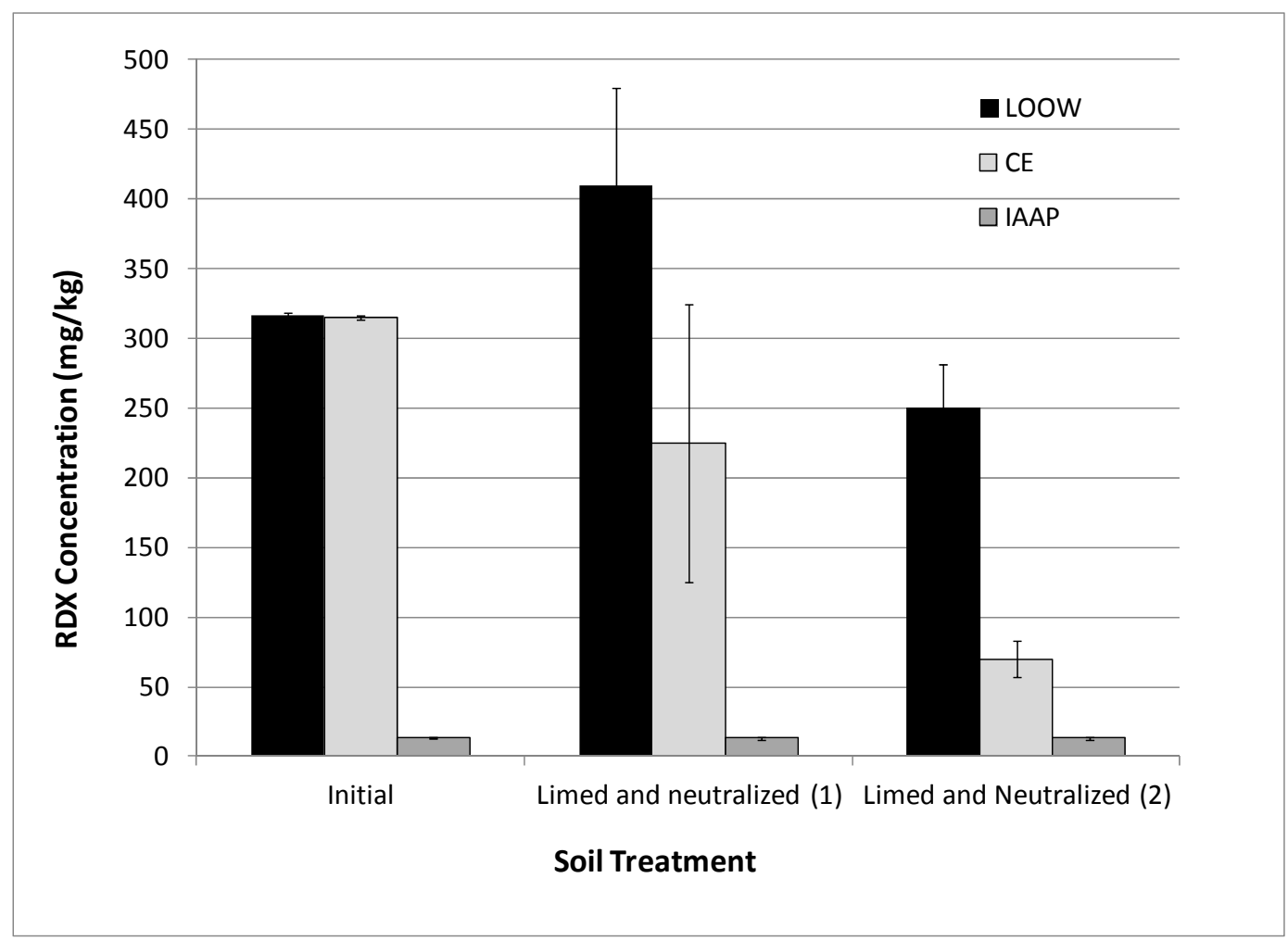

Figure 14. Average concentration of RDX in soil initially and after treatment with $\mathrm{NaOH}$ and neutralization $(\mathrm{mg} / \mathrm{kg}, \mathrm{n}=3$ )

Comfort et al. (2003) examined the loss of $\mathrm{RDX}$ at low $\mathrm{pH}$ and reported no appreciable loss even at $\mathrm{pH}$ as low as 2.02. For soils containing RDX, sufficient strong acid should be used in order to facilitate the dissolution and neutralization of the caustic material. Acids used in this study do not pose a hazard of lowering the $\mathrm{pH}$ to the point where $\mathrm{RDX}$ degradation may occur.

TNT is much more tolerant of reduced $\mathrm{pH}$ solutions than RDX. This simplifies the neutralization of soils where TNT is the predominant contaminant of concern. As shown in Figure 15, the TNT levels for Limed and Neutralized (1) samples and for for Limed and Neutralized (2) are similar to the TNT concentrations obtained from the analysis of soil samples that have not been treated with an alkaline hydrolysis material. This study did not analyze the treated soils for the DNTs, amino-DNTs or the diamino-DNTs. Bhadra et al. (1999) reported that acid hydrolysis succesfully degraded the amino-DNT degradation products of TNT.

The ability to double the dose of the stong acid in these soils provides a means to standardize the neutralization step throughout a treatment. The actual number of equivalents of hydroxide present after $\mathrm{NaOH}$ and $\mathrm{HL}$ soil treatment will decrease with time via several mechanisms, including 
reactions with carbonic acid (from the dissolution of carbon dioxide in the atmosphere), buffering by soil minerals, reactions with humic or organic acids, and gradual leaching of the caustic material.

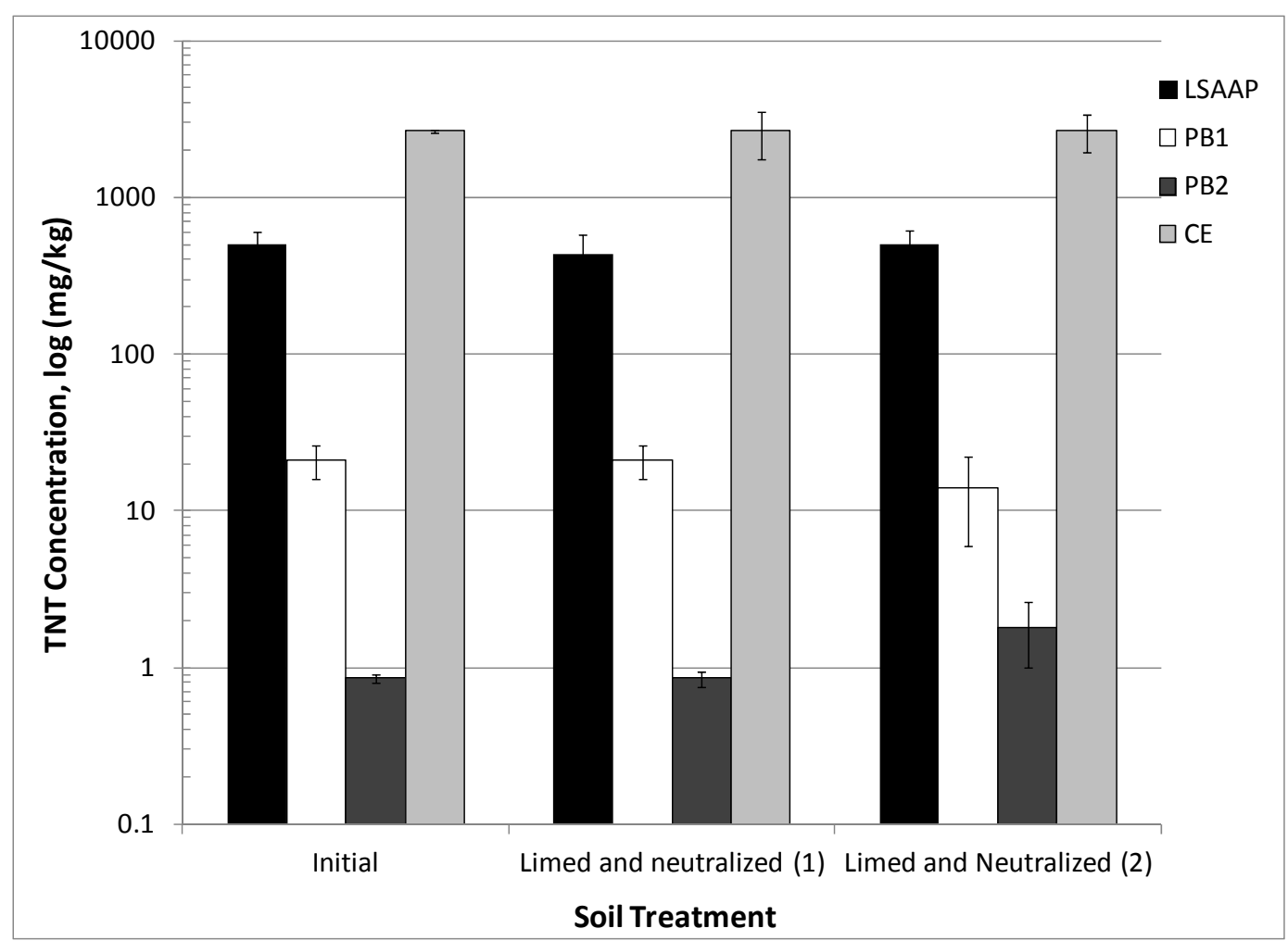

Figure 15. Average concentration of TNT in soils initially and after treatment with $\mathrm{NaOH}$ and neutralization, where Limed and Neutralized (1) entails neutralization using buffer only and Limed and Neutralized (2) entails neutralization using buffer and strong acid. (mg/kg, n=3) 


\section{Conclusions/Discussion}

- The combination of residual caustic material and moisture in soils treated with AH can lead to lower analytical results for explosives; this may lead to the mistaken conclusion that more degradation has occurred than what has actually happened. It can also lead researchers to report false degradation as legitimate results.

- It is possible to neutralize the caustic hydrolysis materials after they are placed in soils to get a more accurate concentration when performing the traditional USEPA Method 8330 analytical procedures.

- Treatment systems using HL are more prone to extraction errors than systems using $\mathrm{NaOH}$, although neutralization improves the accuracy of both treatment approaches.

- The specific mass of the neutralization materials is dependent on the amount of hydroxide source introduced, the type of hydroxide source used, the specific contaminants of concern, and the extent of degradation of the hydroxide source over the course of the remedial action.

- If base hydrolysis is going to be monitored over time and/or for completeness of degradation, then neutralization prior to sonication is the best means to collect quality data. For a given system, a generic neutralization mixture can be prepared for on-site addition of soil or used immediately upon arriving at the laboratory. The neutralized samples can then be air dried, sonicated, and analyzed.

- Care must be taken to ensure that acid neutralization does not result in acid reactions that degrade RDX. The process developed for this study does not reach pHs low enough to result in RDX removal.

- ERDC has developed a neutralization procedure that can be used for alkaline hydrolysis approaches using up to $10 \%$ caustic addition (most systems are less than 5\%). A combination of $\mathrm{H}_{3} \mathrm{PO}_{4}$ and $\mathrm{NaH}_{2} \mathrm{PO}_{4}$ are utilized in the procedure.

- For remedial actions using alkaline hydrolysis, the scope of work for the action should include neutralization of all post-treatment samples with appropriate control samples prepared in order to ensure that neutralization is achieved and that the $\mathrm{pH}$ of the neutralized system is not highly acidic, especially for RDX quantization.

- If lime is being used instead of $\mathrm{NaOH}$, it is generally advisable to allow more time for the $\mathrm{AH}$ reaction to occur before collecting confirmatory 
samples. Waiting seventy-two (72) hours may be a good guideline to follow, although kinetic studies may be useful to consider.

- Due to the shorter activation time of $\mathrm{NaOH}$, respiking might be necessary in $\mathrm{AH}$ projects that utilize this caustic source..

- Table 4 summarizes recommended acids for neutralization depending on the explosives constituents and the caustic used in an $\mathrm{AH}$ treatment scenario.

Table 4. Recommended $\mathrm{pH}$ adjustment protocol for various contaminant mixtures and $\mathrm{AH}$ reagents.

\begin{tabular}{|l|l|l|}
\hline \multirow{2}{*}{ Alkaline Hydrolysis Reagent } & \multicolumn{2}{|c|}{ Contaminants present in soil } \\
\cline { 2 - 3 } Hydrated lime & TNT, DNT only & TNT, DNT and RDX \\
\hline $\mathrm{NaOH}$ & buffer + SA, or SA & buffer + SA \\
\hline
\end{tabular}

Buffer $=$ buffered acid $\left(\mathrm{NaH}_{2} \mathrm{PO}_{4}\right)$,

$\mathrm{SA}=$ strong acid (i.e. $\mathrm{H}_{3} \mathrm{PO}_{4}$ ) 


\section{Acknowledgements}

Funding for this project was provided by the Innovative Technology

Advocate of the Formerly Used Defense Sites (FUDS) Program, which is managed by Mr. Sam Bass, United States Army Corps of Engineers. 


\section{References}

Bhadra, R., G. Wayment, , J.B. Hughes, and J.V. Shanks. 1999. Confirmation of conjugation processes during TNT metabolism by axenic plant roots. Environ. Sci. Technol. 33: 446-452.

Britto, R., M. Patel, and M.L. Spangberg. 2010. Full-scale Alkaline Hydrolysis of TNT and DNT in Soil. Proceedings of the Batelle Seventh International Conference for Remediation of Chlorinated and Recalcitrant compounds.

Brooks, M.C., J.L. Davis, , S.L. Larson, D.R. Felt, , C.C. Nestler. 2003. Topical lime treatment for containment of source zone energetics. ERDC/EL TR-03-19. Vicksburg, MS: Engineering Research and Development Center.

Comfort, S.D., P.J. Shea, T.A. Machacek, , and T. Satapanajaru. 2003. Pilot-scale treatment of RDX-contaminated soil with zerovalent iron. J . Environ. Qual. 32: $1717-1725$.

Davis, J.L., M.C. Brooks, S.L. Larson, C.C. Nestler., and D.R. Felt. 2006. Lime Treatment of Explosives-Contaminated Soil from Munitions Plants and Firing Ranges. Soil and Sediment Contamination: An International J ournal 15(6): 565-580.

Davis, J.L., M.C. Brooks, S.L. Larson, C.C. Nestler, and D.R. Felt. 2007. Lime Treatment for Containment of Source Zone Energetics Contamination: Mesocosm Study. Practice Periodical of Hazardous, Toxic, and Radioactive Waste Management 11(1): 11-19.

Felt, D.R., S.L. Larson, E.J. Valente.2002. UV-VIS Spectroscopy of 2,4,6-trinitrotolueneHydroxide Reaction. Chemosphere 49, 287-295.

Felt, D.R., A.J. Bednar, , and T. Georgian 2008. The effects of grinding methods on metals concentrations in soil. Talanta 77, 380-387.

Johnson, J.L., J.L. Davis, and C.C. Nestler. 2010. Topical LimeApplication for the Management of Muntion Constituents Following Blow-In-Place Operations. ERDC/EL TR-10-10. Vicksburg, MS: Engineering Research and Development Center.

Larson, S.L., J.L. Davis, W.A. Martin, D.R. Felt, C.C. Nestler, D.L. Brandon, G. Fabian, , and G. O'Connor.2007. Grenade range management using lime for metals immobilization and explosives transformation. ERDC/EL TR-07-5. Vicksburg, MS: Engineering Research and Development Center.

Larson, S.L., W.A. Martin, B.L. Escalon, and M. Thompson. 2008a. Dissolution, Sorption, and Kinetics Involved in Systems Containing Explosives, Water, and Soil. ES\&T 42(3): 786-792. 
Larson, S.L., J.L. Davis, W.A. Martin, D.R. Felt, C.C. Nestler, G.L. Fabian, G. O'Connor, G. Zynda, , and B.A. Johnson. 2008b. Grenade range management using lime for metals immobilization and explosives transformation: Field Demonstration at Fort J ackson, SC. ERDC/EL TR-o8-24. Vicksburg, MS: U.S. Army Engineer Research and Development Center.

Medina, V.F., S. Waisner, A. Morrow, C.C. Nestler, and M. Jones. 2007. Evaluation of Lime and Persulfate Treatment of Soils from the Plum Brook Ordnance Works. ERDC/EL TR-07-19. Vicksburg, MS: U.S. Army Engineer Research \& Development Center Report.

Österreicher-Cunha, P., T. Langenbach, J. P. M. Torres, A. L. C. Lima, T. M. P. de Campos, E. d. A.Vargas, Jr., and A. R.Wagener. 2003. HCH distribution and microbial parameters after liming of a heavily contaminated soil in Rio de Janeiro. Environmental Research 93(3): 316-327.

Shaw Environmental, Inc. 2008. Submittal of the Addendum for the TNT Area A. TNT Areas A and C Focused Feasibility Study for Soil and Sediment. Former Plum Brook Ordnance Works. Sandusky, OH. Contract No. W912DR-05-D-0026; Shaw Project Number 119298. Prepared for U.S. Army Corps of Engineers, Nashville District.

Tetra Tech, Inc., 2008a. Summary of Bench Scale and Field Treatability Tests, Chemical Treatment of TNT and DNT-Contaminated Soil, TNT Manufacturing Valley, Volunteer Army Ammunition Plant, Chattanooga, Tennessee, prepared for the U.S. Army Corps of Engineers, Mobile District, January.

Tetra Tech, Inc., 2008b. Final Addendum to the Corrective Measures Implementation Work Plan for the TNT Manufacturing Valley (VAAP-32), Volunteer Army Ammunition Plant, Chattanooga, Tennessee, Soil Implementation Work Plan for Full-Scale Treatment, Chemical Treatment of TNT and DNT-Contaminated Soil, prepared for the U.S. Army Corps of Engineers, Mobile District, January.

U.S. Environmental Protection Agency (USEPA). 1999. Test methods for evaluating solid waste: Physical/ Chemical methods. SW-846. Washington, DC: USEPA.

Waisner, S., V.F. Medina, A.B. Morrow, and C. C. Nestler. 2008. Evaluation of chemical treatments for a mixed contaminant soil. J ournal of Environmental Engineering 134(9): 743-749. 


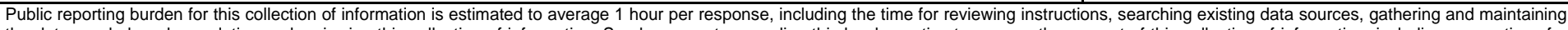

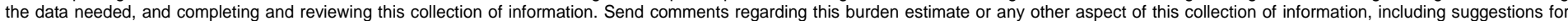

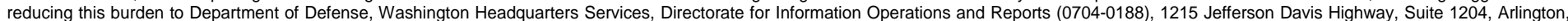

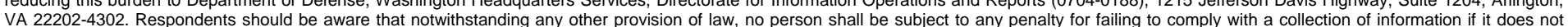
display a currently valid OMB control number. PLEASE DO NOT RETURN YOUR FORM TO THE ABOVE ADDRESS.
1. REPORT DATE (DD-MM-YYYY)
September 2012

4. TITLE AND SUBTITLE

The Effect of Acid Neutralization on Analytical Results Produced from SW846 Method 8330 after the Alkaline Hydrolysis of Explosives in Soil
3. DATES COVERED (From - To)

5a. CONTRACT NUMBER

5b. GRANT NUMBER

5c. PROGRAM ELEMENT NUMBER

5d. PROJECT NUMBER

5e. TASK NUMBER

5f. WORK UNIT NUMBER

8. PERFORMING ORGANIZATION REPORT NUMBER

ERDC/EL TR-12-14

10. SPONSOR/MONITOR'S ACRONYM(S)

11. SPONSOR/MONITOR'S REPORT NUMBER(S)

\section{DISTRIBUTION / AVAILABILITY STATEMENT}

Approved for public release; distribution unlimited.

\section{SUPPLEMENTARY NOTES}

\section{ABSTRACT:}

Alkaline hydrolysis has been used in several laboratory studies and field demonstrations for the treatment of energetic compounds (particularly, 2,4,6-trinitrotoluene (TNT), dinitrotoluene (DNT), and hexahydro-1,3,5-trinitro-1,3,5-triazine (RDX)) in soil. The application of alkaline hydrolysis for treatment of soil involves mixing a caustic source material with soil. Two caustic materials have been explored, calcitic hydrated lime $\left[\mathrm{Ca}(\mathrm{OH})_{2}, \mathrm{HL}\right]$ and sodium hydroxide $(\mathrm{NaOH})$. Evaluation of explosives removal is routinely performed using SW-846 Method 8330. This method was developed before the advent of alkaline hydrolysis treatment, and recent studies have indicated that some errors can occur when this method is applied to alkaline hydrolysis samples. This report documents the results of a field study, conducted to demonstrate the issue of false degradation in field-collected samples. The field study was followed by two laboratory studies: the first to confirm false degradation as a phenomenon and the second to develop an appropriate acid neutralization method. Results proved that false degradation can occur with alkaline hydrolysis (AH) samples, particularly if residual caustic material and moisture are present in the sample. Treatment systems using HL are more prone to extraction errors than systems using $\mathrm{NaOH}$, although neutralization improves the accuracy of both treatment approaches. ERDC-EL has developed a neutralization method that can be used for alkaline hydrolysis approaches using up to 10\% caustic addition (most systems are less than 5\%) and a combination of $\mathrm{H}_{3} \mathrm{PO}_{4}$ and $\mathrm{NaH}_{2} \mathrm{PO}_{4}$. For remedial actions using alkaline hydrolysis, the scope of work for the action should include neutralization of all post- treatment samples, with appropriate control samples prepared in order to ensure that neutralization is achieved.

15. SUBJECT TERMS

\section{SECURITY CLASSIFICATION OF:}

a. REPORT

UNCLASSIFIED

b. ABSTRACT
UNCLASSIFIED

c. THIS PAGE

UNCLASSIFIED 17. LIMITATION
OF ABSTRACT

18. NUMBER OF PAGES

37 19a. NAME OF RESPONSIBLE PERSON

19b. TELEPHONE NUMBER (include area code) 